\title{
The effectiveness of the fiscal policy response to COVID-19 through the lens of short and long run labor market effects of COVID-19 measures
}

PATRIK BARIŠIĆ, mag. oec." TIBOR KOVAČ, mag. oec."

Article**

JEL: E62, E32, E27, O40

https://doi.org/10.3326/pse.46.1.2

\footnotetext{
* The views presented in this paper are the authors' own and do not necessarily reflect the official position of the Croatian National Bank nor the Institute of Economics, Zagreb. We want to express gratitude towards our university professor doc. dr. sc. Ozana Nadoveza Jelić. Her insights have been invaluable in the creation of this research paper. Also, we would like to thank two anonymous reviewers for their thoughtful comments and efforts, which have improved our paper.

The article won the award for the best student category paper in the annual 2021 Prof. Dr. Marijan Hanžeković Trust Competition.

${ }^{* *}$ Received: June 1, 2021

Accepted: November 4, 2021

\section{Patrik BARIŠIĆ}

Croatian National Bank, Trg hrvatskih velikana 3, 10000 Zagreb, Croatia

e-mail: patrikbarisic97@gmail.com

ORCiD: 0000-0002-0199-4102

Tibor KOVAČ

The Institute of Economics, Zagreb, Trg J.F. Kennedy 7, 10000 Zagreb, Croatia

e-mail: tibor.kova97@gmail.com

ORCiD: 0000-0003-2941-6934
} 
Abstract

Lack of information on the adequacy of fiscal measures undertaken in the COVID19 crisis and its long-term adverse effects on economic growth and labor market outcomes has raised debates about the impact of fiscal austerity and fears of slower recovery from the ongoing economic downturn. This paper analyzes the short and long-term effects of the fiscal policy measures undertaken in the COVID19 crisis in the EU-27. For the short-term estimation, we use Okun's law. To examine the long-run effects, we use the concept of potential output using a production function approach. The findings from this paper are that in the short-term, fiscal measures were generally effective. In the long-term, the COVID-19 crisis would have had a negative and permanent effect on the potential GDP growth if the policymakers had undertaken no fiscal measures.

Keywords: COVID-19, fiscal response, unemployment, Okun's law, potential output

\section{INTRODUCTION}

The coronavirus disease 2019 (COVID-19), which appeared in most countries at the beginning of 2020, was soon declared by World Health Organization (WHO) a Public Health Emergency of International Concern or a Pandemic. Up to date, over 159 million people have been infected by the disease, and over 3 million have lost their lives. ${ }^{1}$ The COVID-19 pandemic has caused a vast health crisis and triggered an unprecedented economic crisis around the world. As COVID-19 poses a significant threat to human lives, policymakers implemented lockdowns and other measures, such as social distancing, to prevent and contain the spread of the disease. By implementing these measures, policymakers saved many lives (Yoo and Managi, 2020). As these measures involved multiple restrictions on flows of people, goods, and services, many businesses were shut down, producing a significant economic crisis called the COVID-19 crisis.

Each country has been affected differently by the pandemic and accordingly responded differently (Brauner et al., 2021). As responses varied across countries, this also caused different impacts on economies and their growth prospects. The global financial crisis was characterized as an event that had prolonged effects on the economy, affecting firms, investors, workers, and consumers, because policymakers had not given enough or adequate policy support to their economies (Ball, 2014; Rawdanowicz et al., 2014; Reifschneider, Wascher and Wilcox, 2015; Cerra and Saxena, 2017). This raised the question about adequate policy support in the ongoing COVID-19 crisis since literature offers plenty of evidence that fluctuations of GDP can be persistent, which means that any shock that occurs in the economy can have scarring effects for years after the initial shock has taken place. Thus, these cyclical fluctuations of GDP affect the trends, a relationship known as hysteresis and it is important that policymakers counteract low aggregate demand and bring the economy back to its full working capacity.

${ }^{1}$ As of May 12, 2021 (WHO, 2021). 
In order to assess the economic damage that the COVID-19 crisis has done, this paper aims to analyze the short-run effectiveness of the fiscal policy support in the first two quarters of 2020 and possible long-run impacts on the potential GDP through the lens of estimated labor market effects. Our analysis is based on the sample of all European Union (EU) countries, with the exclusion of Luxembourg since it is an outlier, which will be further explained in the paper.

The paper is organized as follows. After the introduction, the second chapter provides a literature overview and empirical evidence of how COVID-19 has affected output in the short term and how it can affect it in the long term. This chapter focuses on the hysteresis effect, where crises such as the ongoing COVID-19 crisis cause deviations of GDP from its natural level in the short term and possibly leave scars in the long term. The chapter also emphasizes the importance of implementing stabilization policies to reduce deviations of GDP from its natural level. Those fluctuations tend to be persistent and can have adverse effects on the economy that remain present for years after the shock. The third chapter briefly describes Okun's law, a methodology used to assess the short-term effects and the potential effects of fiscal measures in the long run, using potential output that is estimated using the production function method. The results of this paper are presented in the fourth chapter. Results indicate that selected European countries' fiscal policy measures taken in the COVID-19 crisis were generally effective in the short run. However, the long-term effects of the COVID-19 crisis would have had an adverse and permanent effect on the potential GDP growth if the policymakers had undertaken no fiscal measures. The last chapter summarizes the main findings and concludes with implications for economic policies.

\section{LITERATURE REVIEW}

There is not much evidence in the literature on how pandemic-type crises such as that of COVID-19 can affect short-term and long-term output dynamics. However, several theoretical frameworks have been created during the past year to assess the potential impact of the COVID-19 crisis on both short-term and longterm output (Fornaro and Wolf, 2020; Bodnár et al., 2020). Furthermore, research into past crises, such as the global financial crisis, and other studies which examine impacts of different epidemiological (Barro, Urs'ua and Weng, 2020; Jord'a, Singh and Taylor, 2020) and environmental factors (Bloom et al., 1998; Barrios, Strobl and Bertinelli, 2010) can be good indicators of how the COVID-19 crisis can affect economic activity (Gonzales-Castillo et al., 2020).

The macroeconomic shock caused by the COVID-19 pandemic affected both supply and demand at the same time. The pandemic started as a supply-side shock because government interventions imposed unprecedented supply-side restrictions to contain the spread of the virus. This supply-side shock appeared as a combination of several supply-side restrictions, such as lockdowns, supply chain disruptions, firm bankruptcies, unemployment that downgraded workers' skills, and corporate debt that creates zombie firms. The nature of this supply-side shock is that it is supposed to be temporary because closure measures have been assumed to be 
temporary. It is expected that supply-side shock should disappear after the conditions for the abolition of closure measures are created, i.e., when there are fewer infections. In the meantime, this supply-side shock has turned into a demand-side shock because high uncertainty tends to appear in tough times, which are now related to the pandemic (Bloom, 2009). All of this led to a fall in consumption and a rise in savings, and the concomitant fall in aggregate demand. In the short term, as aggregate demand falls, a fall in output is created, which causes a fall in employment, a rise in unemployment, and a decline in investments. A drop in aggregate demand is usually linked with output fluctuations around potential output, creating business cycle fluctuations. A fall in aggregate demand and overly pessimistic forecasts of lower long-term growth of output can impact the economy through underinvestment or loss of innovation potential and cause fiscal tightening due to policymakers having to enact fiscal consolidation because of lower long-run growth in output (Fornaro and Wolf, 2020; Benedetti, Sedláček and Ster, 2020; Heimberger, 2020). The problem occurs if the supposed temporary supply-side shock becomes permanent, leading to a supply-side constraint. All these cause worries related to "hysteresis", which economists often use to explain the long-lasting damage effects of sharp recessions on output (Blanchard and Summers, 1986).

After pioneering papers by Nelson and Plosser (1982) and Campbell and Mankiw (1989), who showed that fluctuations in output tend to be persistent in the United States (US) and G7 countries, in the last decade there has been a growing body of research that has examined the impact of recessions on long term output dynamics. Research conducted by Cerra and Saxena (2008) and Reinhart and Rogoff (2009) concluded that deep recessions, such as the COVID-19, have persistent effects on output. Ball (2014) also quantified the damage in 23 countries of the Organization for Economic Co-operation and Development (OECD) that the global financial crisis did in 2008-2009. The author concluded that most countries had experienced strong hysteresis effects. Moreover, potential output losses accumulate over time (Rawdanowiczi et al., 2014; Reifschneider, Wascher and Wilcox, 2015; Cerra and Saxena, 2017). Blanchard, Cerutti and Summers (2015) found that a high number of recessions have been followed with lower output and lower output growth, and they concluded that demand shocks could affect output permanently.

The development of endogenous growth models created a vast number of potential sources that could cause hysteresis. Some of these theories emphasize the importance of changes in capital and knowledge accumulation (King, Plosser and Rebelo, 1988; King and Rebelo, 1988), human capital, and learning by doing as the key sources in explaining the long-run growth of output, as their procyclicality directly affects long-run growth (Stadler, 1986; 1990; Stiglitz, 1993). Stadler (1990) showed that investment and R\&D expenditures tend to be lower or subdued during the recession period compared to the "normal" periods. Also, some authors (e.g., Haltmaier, 2013, and Reifschneider, Wascher and Wilcox, 2015) show that cyclical variations of total factor productivity (TFP) are responsible for explaining long-lasting effects on output growth because recessions damage economies' labor force and productivity, which reduces potential output. 
Thus, empirical evidence raises concerns about the effects of the COVID-19 crisis on output in both the short and long run since output fluctuations seem to be persistent. The hysteresis effect, which is particularly pronounced in the labor market, impacts policymakers too. Pessimistic views about future potential output levels provide incentives for inadequate policy support and enact fiscal consolidation, consequently creating persistence and, thus, lowering the potential output even more (Heimberger, 2020). Research by Fatas and Summers (2018) provides evidence that countries that implemented large fiscal consolidations during the recession periods experienced much more severe persistent effects on GDP. Similarly, Gechert, Horn and Paetz (2019) produced the same conclusion and provided additional confirmation. Also, DeLong and Summers (2012) showed that fiscal consolidation in an economy in a recession could be self-defeating because it can increase debt. Furthermore, IMF (2009), Cerra, Panizza and Saxena (2012), and Ma, Rogers and Xhou (2020) showed that in the aftermath of a recession, macroeconomics policies such as more aggressive fiscal and monetary stimuli tend to help economies to have lower output losses over the medium term.

The goal of policymakers is to reduce deviations of actual output from its potential level. Implementation of stabilization policies reduces deviations of actual GDP around its potential level and can also potentially raise its average level (Cohen, 2000; Dupraz, Nakamura and Steinsson, 2019). To overcome the shortrun costs of the COVID-19 crisis and its possible scarring effects in the long run, many scientists and policymakers emphasized the need for adequate economic (especially fiscal) policy support. This paper assesses the effectiveness of discretionary fiscal policy support to combat the COVID-19 crisis in the short term, given in the first two quarters of 2020, and analyzing the impact of the COVID-19 crisis on potential GDP, and assessing what would have been the level of potential GDP without these fiscal measures. There are several transmission mechanisms by which COVID-19 has spilled over into the economy that can influence potential output in the long run. However, in this paper, we focus on the labor market performance because many governments have tried to mitigate the effects in that market due to the possible existence of hysteresis.

The existence of hysteresis on the labor market in Europe was first brought up by Blanchard and Summers (1986) after the economic crisis in the 1970s, after which unemployment rates stayed at a higher level than would have been expected based on macroeconomic and labor market frictions (Blanchard and Summers, 1986). In addition, they argue that this could lead to the rise of non-accelerating inflation rate of unemployment. Furthermore, labor market hysteresis presence was confirmed in euro area countries, especially in Germany (Loageay and Tober, 2005). The same results were found in some Central and Eastern European countries (Gozgor, 2013). There are several proposed sources of hysteresis, such as the insider-outsider model of the labor market (Blanchard and Summers, 1986) or the design of institutions (Di Tella and MacCulloch, 2006). Keeping that in mind, recessions produce disruptions in labor markets (Hershbein and Stuart, 2020), and 
the last recession in 2008 increased rates of long-term unemployment (Kroft et al., 2014), which plays a crucial role in the presence of hysteresis (Bell, 2009). The human capital of the unemployed decreases over time, possibly to the level under the reservation wage (Blanchard, 1991), making long-term unemployed workers unattractive to employers. To fight long-term unemployment, active labor policies should be used (Bentolila, García-Pérez and Jansen, 2017).

\section{DATA AND METHODOLOGY}

This paper uses data for 26 EU countries, with only Luxembourg being left out. Luxembourg is the only country in the sample that experienced constant growth of unemployment rate regardless of changes in GDP, and due to that, we decided to leave it out.

To test the effectiveness of COVID-19-induced fiscal policy measures in the short run, we estimate and forecast unemployment rates in selected European countries. To do so, we use Okun's law relation, which relates unemployment and output. Furthermore, for examining long-run effects, we use the concept of potential output, which is estimated with a production function. We use standard production function, with working-age population, participation rate, and output elasticities of labor. Table 1 shows a description of all data used in the analysis.

\section{TABLE 1}

Description of the variables

\begin{tabular}{|c|c|c|c|c|}
\hline Variable & Period & Frequency & Database & Description \\
\hline $\begin{array}{l}\text { GDP at } \\
\text { market prices }\end{array}$ & $\begin{array}{l}\text { 1999Q1-2020Q4 } \\
\text { (Malta from 2000) }\end{array}$ & Quarterly & Eurostat & $\begin{array}{l}\text { Unite }=\text { chain linked } \\
\text { volumes, index } \\
2015=100, \\
\text { seasonally and } \\
\text { calendar adjusted } \\
\text { data }\end{array}$ \\
\hline $\begin{array}{l}\text { Unemployment } \\
\text { rate }\end{array}$ & $\begin{array}{l}\text { 1999Q1-2020Q4 } \\
\text { (Bulgaria from 2000; } \\
\text { France from 2003) }\end{array}$ & Quarterly & Eurostat & $\begin{array}{l}\text { Unite=percentage } \\
\text { of population in } \\
\text { the labor force, } \\
\text { sex=total, trend } \\
\text { cycle data }\end{array}$ \\
\hline $\begin{array}{l}\text { Working age } \\
\text { population }\end{array}$ & $\begin{array}{l}2000-2020 \\
\text { (France from 2003) }\end{array}$ & Annual & Eurostat & $\begin{array}{l}\text { Unite=number, } \\
\text { sex=total }\end{array}$ \\
\hline $\begin{array}{l}\text { Active (persons) } \\
\text { population }\end{array}$ & $\begin{array}{l}2000-2020 \\
\text { (France from 2003) }\end{array}$ & Annual & Eurostat & $\begin{array}{l}\text { Unite }=\text { percentage } \\
\text { of total population, } \\
\text { sex=total }\end{array}$ \\
\hline $\begin{array}{l}\text { Output elasticity } \\
\text { of labor }\end{array}$ & 2000-2019 & Annual & $\begin{array}{l}\text { Penn World Table } \\
\text { (Feenstra, Inklaar } \\
\text { and Timmer, 2015) }\end{array}$ & \\
\hline
\end{tabular}

Source: Authors. 
To test the short-run effectiveness of COVID-19 fiscal measures, we estimate and forecast unemployment rates in selected European countries, for which Okun's law relation is used. The well-known Okun's (1962) law relates output and unemployment. Okun's law relation is one of the most frequently used relations in the economy, commonly used by the European Central Bank (e.g., Anderton et al., 2014), and provides helpful information to policymakers. The main reason behind choosing Okun's law to assess the effects of the fiscal policy response to the coronavirus pandemic is due to its simplicity and relevance. Furthermore, Okun's law is robust when applied to European countries (Economou and Psarianos, 2016), and it stayed consistent during the Great Recession in the USA (Ball, Leigh and Loungani, 2013). Although simple, this approach allows us to estimate how the unemployment rate would change due to actual changes in GDP if no fiscal measures were imposed, as opposed to the actual rates. Due to the lack of detailed data and uncertainty regarding the pandemic, this approach can be used as a benchmark for future research when more detailed data on fiscal stimulus structure become available.

Two main approaches of Okun's law are commonly used in the analysis. The first focuses on the relationship between the GDP growth rate and change in unemployment, and the second relates the deviation of the unemployment rate from its natural level and the deviation of GDP from its potential level (or growth). The following equation typically represents the first approach:

$$
\Delta u_{\mathrm{t}}=\alpha+\beta \Delta y_{\mathrm{t}}+\varepsilon_{\mathrm{t}}
$$

where $\Delta u_{\mathrm{t}}$ stands for the change in the unemployment rate at the time $t, \Delta y_{\mathrm{t}}$ is a change in output in time $t$, and $\varepsilon_{\mathrm{t}}$ is an error term that is normally distributed $\operatorname{IID}(0$, $\sigma^{2}$ ). Considering coefficients, $\alpha$ is a constant representing the long-run growth trend in unemployment, $\beta$ represents Okun's coefficient, which measures the response of the unemployment rate to changes in output. Response of unemployment due to change in output is expected to be negative, which arises from the general relationship between unemployment and output. That is, a higher output generally leads to lower unemployment. The second approach is associated with unemployment and output gap and is typically estimated using the following equation:

$$
u_{\mathrm{t}}-u_{\mathrm{t}}^{*}=\alpha+\beta\left(y_{\mathrm{t}}-y_{\mathrm{t}}^{*}\right)+\varepsilon_{\mathrm{t}}
$$

where $u_{\mathrm{t}}-u_{\mathrm{t}}^{*}=u_{\mathrm{t}}^{c}$ is a gap (cycle) between observed and potential unemployment rate, $y_{\mathrm{t}}-y_{\mathrm{t}}^{*}=y_{\mathrm{t}}^{c}$ is a gap (cycle) between observed and potential output. However, as Jovičić (2017) demonstrates, all commonly used methods of estimating potential output are particularly uncertain in real-time because estimates at the end of the sample can change significantly with the publication of new data, which is also called the end-of-sample problem. This property of potential output (or natural 
unemployment rate) estimates can result in significant revisions of current and historical potential output as new information throughout time arrives. Also, in periods of economic crisis when the future is completely uncertain, the difficulty of assessing potential output is especially pronounced. This uncertainty and potentially significant revisions are problematic because that information on the output gap is least certain at the very moment when it is most important to economic policymakers. This uncertainty can lead to unreliable estimates of the output gap that can result in wrong decisions and moves by monetary and fiscal authorities. Because of the mentioned problems, we will not estimate equation (2), and therefore, only the first approach is used in this paper. Also, we estimate equation (1) as of 2019:Q4, and then we forecast the unemployment rate level conditionally on the realized rates of change in GDP.

To have technically correct estimations of equation (1), which we estimate using the ordinary least squares method (OLS), it is necessary to ensure the external and internal validity of regression analysis (Stock and Watson, 2011). External validity is associated and achieved with a representative sample, while internal validity is associated and achieved if the estimator is unbiased and consistent and if standard errors are valid. To achieve internal validity, assumptions of homoskedasticity and autocorrelation must be satisfied. Therefore, it is necessary to test for problems of heteroskedasticity and autocorrelation that may arise when estimating equation (1). Potential problems are detected by diagnostic tests, where for the potential problem of heteroskedasticity, the Breusch-Pagan test is used, which is a commonly used test to detect the problem of heteroskedasticity. For detection of the potential problem of autocorrelation, the Breusch-Godfrey test is used, which is also a standard test in literature.

The problem of autocorrelation is solved by adding one or up to two lags of the dependent variable, depending on the country. The reason for using up to two lags is that, by adding more than two lags, the problem of autocorrelation is not being solved and remains persistent, no matter how many lags of the dependent variable are added. However, by adding more than two lags of the dependent variable, the fit of the model is still strongly robust. Because of the problem of heteroskedasticity, the variance is stabilized by following Stockhammar and Oller (2012) and using the generalized autoregressive conditional heteroskedastic model (GARCH), estimated by the following equation:

$$
\sigma_{t}^{2}=\alpha_{o}+\alpha_{1} \varepsilon_{t-1}^{2}+\beta_{1} \sigma_{t-1}^{2}
$$

where equations (1) and (3) represent the GARCH $(1,1)$ model, which is used in this paper, where in equation (3), variance $\sigma_{t}^{2}$ in time $t$ is a function of lagged squared error terms $\varepsilon_{t-1}^{2}$ and lagged variance $\sigma_{t-1}^{2} \cdot \alpha_{o}$ represents intercept, $\varepsilon_{t-1}^{2}$ represents the ARCH term and $\sigma_{t-1}^{2}$ represents the GARCH term. This procedure is also used if the problem of autocorrelation is still present after up to two lags of the dependent variable are added. 
As for tackling the problem of autocorrelation, on the right side of equation (1), lagged values of growth of GDP will be added. This will turn equation (1) into a dynamic version of Okun's law. This dynamic version of Okun's law is fundamentally different from the simple difference version, as it does not capture the contemporaneous relationship between changes in the growth of GDP and unemployment. The advantage of the dynamic version is that it is not restrictive when considering the timing of the connection between changes in the growth of GDP and unemployment. The drawback of the dynamic version is that it does not have a simple interpretation as compared to the version with the growth of the GDP in time $t$ (Knotek, 2007).

To determine the effectiveness of discretionary fiscal policy in fighting the COVID-19 crisis, equation (1) is estimated for each country. To satisfy technical requirements, as mentioned above, lags of the GDP and unemployment are added, and the GARCH is used if needed. Additionally, equation (1) with only two lags of GDP is estimated. These results are used to test robustness. Equations are estimated until 2019:Q4, and then after that, we use these estimations to forecast future values of unemployment for the first two quarters of 2020 based on the actual fall in GDP. Forecasted values represent unobservable unemployment rates that are consistent with the actual drop in GDP, and we use these predicted values to approximate unemployment changes in a situation in which no fiscal measures were imposed to fight the ongoing crisis. It is important to emphasize that although in this situation we assume that there are no fiscal measures imposed, we do not neglect the existence of imposed measures to fight the spread of the virus, rather we assume that they are imposed and are affecting GDP. Therefore, their impact is contained in the fall in GDP itself. In the end, we compare whether actual values of the unemployment rates, i.e., those that are under the influence of fiscal stimulus proposed to combat the COVID-19 crisis, are higher or lower than those forecasted. If the forecasted are higher than the actual values, we conclude that countries' fiscal policy measures were effective, and vice versa.

\subsection{LONG-RUN EFFECTS OF THE COVID-19 FISCAL MEASURES}

Firstly, it is important to emphasize that even though we examine effects three years ahead, which can hardly be characterized as the long run, we do estimate potential output effects, which are generally perceived as a long-run variable, so we use the term "long-run effects". In addition, the reason for examining effects only three years ahead comes from the ARIMA forecasting technique we are using. Forecasting too much ahead leads towards the long-term average, which leads to the equalization of unemployment rates with and without fiscal measures. Furthermore, here also lies the reason for using annual data. With annual data, we forecasted values only three years in advance, while with quarterly data, we should forecast 12 quarters in advance, which would, in our opinion, increase uncertainty, and convergence towards the long-term average would occur earlier. To estimate the potential long-run effects of fiscal measures, we use the concept of potential output estimated using the production function approach based on the Cobb-Douglas production function. Due to the simplicity of the Cobb-Douglas 
production function, labor contribution to potential output can be easily isolated and interpreted. More precisely, the impact of the fiscal policy measures on unemployment in the short-term to potential output can be estimated.

In doing so, we construct two scenarios. In the first scenario, we assume that in the absence of a fiscal policy response (but, as mentioned earlier, in the presence of measures that aim to fight the spread of the virus) the unemployment rate would rise to a level consistent with Okun's law and we then forecast the three-year unemployment rate using a simple AR model. In the second scenario, we use actual data and forecast the unemployment rate in the same way. All other components of the production function are assumed to be the same in both scenarios. Using forecasted unemployment rates, we calculate two alternative paths of potential output and calculate the difference between the forecasted growth rate of potential GDP in both scenarios. The difference between the two scenarios gives us an estimate of the effects of the fiscal measures on the potential output and its growth on the prognostic horizon.

For estimating the effect of change in the unemployment rate on potential output and its growth rate, we use the standard Cobb-Douglas production function (4):

$$
Y=A L^{\alpha} K^{\beta}
$$

where $Y$ is total production, $L$ is labor input, $K$ is capital input, $A$ is total factor productivity (TFP), and $\alpha$ and $\beta$ are the output elasticities of labor and capital, respectively. TFP and capital are kept unchanged between the two scenarios to isolate the effect of differences in unemployment rates on potential output and growth. By log differencing equation (4) and taking partial derivative with respect to labor, we get:

$$
d\left(\ln Y_{t}\right)=\alpha \times d\left(\ln L_{t}\right)
$$

where $Y$ represents potential GDP, $\alpha$ stands for output elasticities of labor, and $L$ is labor. Labor (employment) is given by the following identity:

$$
L_{t}=\left(1-u_{n t}\right) \times \text { part }_{n t} \times r s s_{t}
$$

In equation (6), $u_{n t}$ represents natural unemployment rate, part $_{n t}$ is trend participation rate and $r s s_{t}$ stands for the working-age population. To see the effect of fiscal measures, we need to compare the expected growth of potential GDP between two scenarios (with and without fiscal measures) which affected the unemployment rate. To do that, we estimate the natural unemployment rate from actual unemployment data, representing situations with fiscal measures using the HodrickPrescott (HP) filter. For the situation without fiscal measures, we modify data in 2020 based on estimations and forecast of our models (Okun's law), and again, using the HP filter, we estimate the alternative natural unemployment rate path. ${ }^{2}$

\footnotetext{
${ }^{2}$ Although the mentioned end-of-sample problem could be an issue, as explained in the previous section, we acknowledge that it is less of an issue in this case because we use forecasted values here, which lower the endof-sample bias uncertainty. However, forecasted values also bring their own uncertainty.
} 
Natural unemployment rates are kept the same for the period before 2020. As we want to see the effect of fiscal measures on future periods using ARIMA forecasting techniques, we forecast unemployment rates for the three-year horizon (up to 2023). Furthermore, we need a trend participation rate and working-age population for the same period. For that, we use the same procedure. $\alpha$ is not forecasted for a future period, just kept fixed at its last observed value. Once we have all values of all variables until 2023, based on equations (5) and (6) we are ready to make a comparison of potential GDP growth in two scenarios.

\section{RESULTS}

\subsection{SHORT RUN EFFECTIVENESS OF COVID-19 MEASURES}

In this section, the results of the effectiveness of COVID-19 fiscal measures for selected countries are presented. To determine the effectiveness of discretionary fiscal policy in fighting the COVID-19 crisis, equation (1) is estimated for each country. The results from equation (1) that are technically correct are used as main results to determine if fiscal policy measures implemented to tackle the COVID19 crisis in the first two quarters of 2020 were effective. Additionally, equation (1) with only two lags of GDP is estimated, and results are used to test robustness. Equations are estimated until 2019:Q4 and then are forecasted for the first two quarters of 2020. If the forecasted values are higher than actual values, countries' fiscal policy measures were effective, and vice versa.

First of all, equation (1) is estimated with GDP at time $t$, and after that, lagged values of GDP at time $t-1$ and $t-2$ are added, because fitted values of change in the unemployment rate better suit the actual values of the unemployment rate. Adding more than two lagged values of GDP to the equations does not significantly change the fit of the models. To check if equation (1) is technically correct, diagnostic tests of autocorrelation and heteroskedasticity are carried out. To tackle the problem of autocorrelation, lagged values are added, where for some countries, only one lag is added, and for some, two lags are added. The addition of lags increased model fit and has solved the problem of autocorrelation. In countries where adding lags was not enough to solve OLS assumptions, violation problems were solved using the GARCH $(1,1)$ model. ${ }^{3}$ The results for each country from equation (1), with basic OLS estimation, OLS estimation with no autocorrelation problem, and OLS estimation with no heteroskedasticity problem, are presented in appendix A, which shows that those results are very similar, and thus this represents robustness of the given estimations.

Results for equation (1) are presented in figure 1. Figure 1 shows the difference between estimated and actual values of change in the unemployment rate in EU-26

\footnotetext{
${ }^{3}$ The country where GARCH $(1,1)$ model is used in the equation is Ireland due to heteroskedasticity. For the problem of autocorrelation, it is used in Belgium, Estonia, Germany, Greece, Ireland, and Poland. Results are strongly robust. Also, we have estimated different models with different numbers of lags by using either independent variables or a combination of independent and dependent variables and with or without the GARCH $(1,1)$ model. In either case, results remain strongly robust and are available upon request.
} 
countries, where positive values indicate that the fiscal measures implemented do mitigate the increase of unemployment as compared to a situation in which no fiscal stimulus has been given. Negative values indicate that estimated values are lower than actual values, and therefore, the negative impact of fiscal policy measures on the change in the unemployment rate.

\section{Figure 1}

Difference between estimated and actual values of the change in the unemployment rate, 2020:Q1 and 2020:Q2

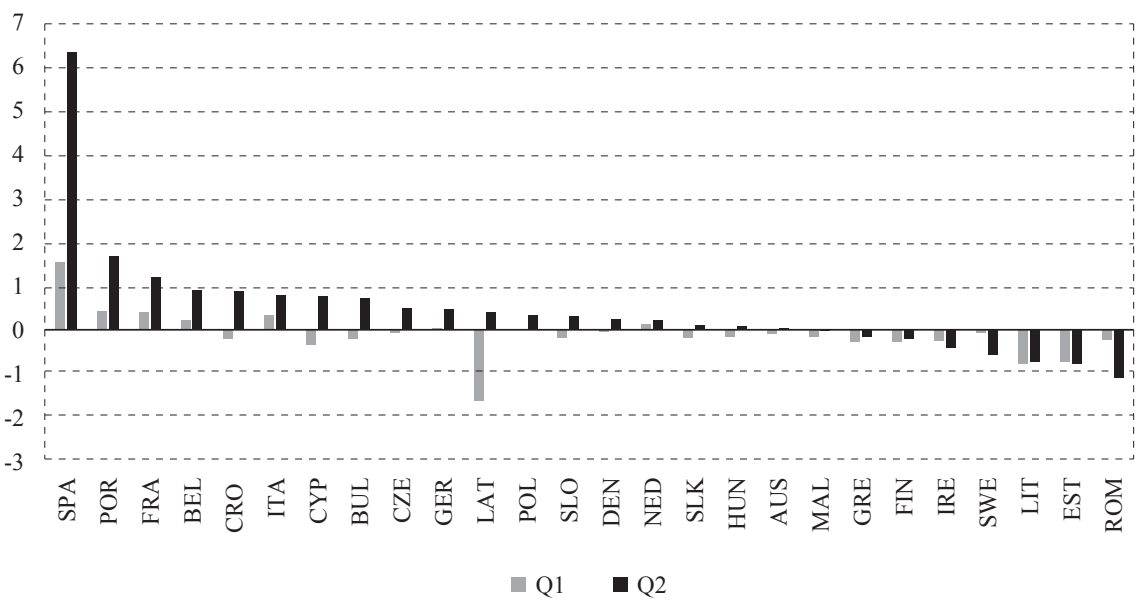

Source: Authors' own calculation based on Labor force survey (LFS) unemployment data by Eurostat (2021).

It can be seen in figure 1 that, in the first quarter of 2020, Spain, Portugal, France, Belgium, Italy, Germany, Poland, and the Netherlands had a positive difference, with Spain first and followed by other mentioned countries, which means that the estimated unemployment rate was higher than the actual unemployment rate, and that indicates the success of implemented fiscal policy measures. The rest of the countries had a negative difference in the first quarter, with Baltic countries having the most ineffective fiscal policy measures undertaken in the first quarter of 2020. However, since the COVID-19 crisis in some countries started after the first quarter, estimated results in the first quarter should be taken with caution. According to that, our focus lies on the second quarter. Results for the second quarter indicate that all countries, except Malta, Greece, Finland, Ireland, Sweden, Lithuania, Estonia, and Romania, had effective fiscal policy measures in the second quarter of 2020, with Spain on top of that list and leading by far which makes Spain the country whose fiscal measures mitigated unemployment growth the most. Countries with effective fiscal policy measures in both quarters are Spain, Portugal, France, Belgium, Italy, Germany, Poland, and the Netherlands.

Furthermore, figure 2 shows the discretionary fiscal response to the COVID-19 crisis, as additional spending or foregone revenue in the non-health sector in the percentage 
of GDP in our EU-26 countries, as of September 11, 2020. ${ }^{4}$ In appendix B, there is a brief summary of non-health fiscal policy measures undertaken in each country from the sample ${ }^{5}$. It shows that countries mostly imposed similar fiscal policies in order to fight the ongoing crisis. In order to preserve employment, countries are mostly subsiding wages and providing financial support for the maintenance of business activity. At the time of writing this paper, we do not have detailed and precise information on the amount of money provided for each fiscal measure, or for the terms under which they are implemented, or what goal a specific fiscal measure has. However, this indicator contains these measures and is currently the best approximation for currently available fiscal measures used to cushion the labor market effects of COVID-19.

\section{Figure 2}

Discretionary fiscal response to the COVID-19 crisis as additional spending or foregone revenue in the non-health sector, as of September 11, 2020 (percentage of GDP)

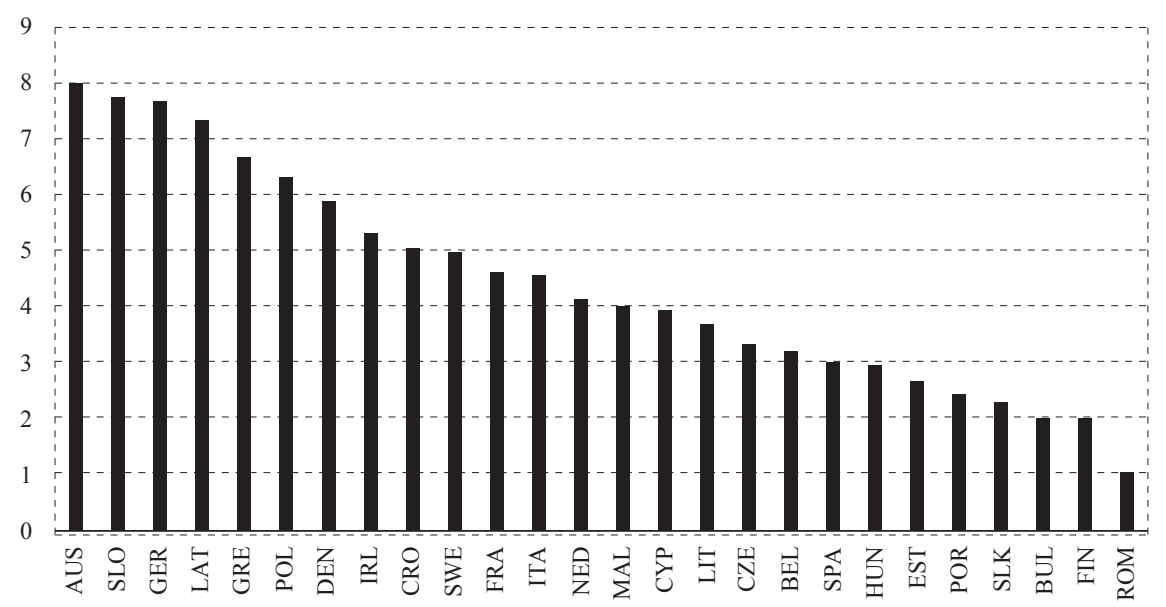

Source: IMF (2020).

It can be seen in figure 2 that Austria, Slovenia, and Germany had the highest nonhealth fiscal response to the COVID-19 crisis, while Bulgaria, Finland, and Romania had the lowest. Comparing figure 2 to figure 1, it can be seen that Spain, Portugal, and Belgium, which were very successful in fighting the COVID-19 crisis in both quarters, spent significantly less in percentage of GDP. Also, Austria, Slovenia, and Germany, which had the highest fiscal response of selected countries, were much less successful in fighting the COVID-19 crisis labor market effects than their peers. All of this can indicate that size of the fiscal response does not necessarily imply the results on the success of fighting against the COVID-19 crisis labor market effects.

Figure 3 shows the ratio between the estimated effectiveness of fiscal measures (shown in figure 1) and discretionary fiscal response (shown in figure 2) for Q2 in 2020.

\footnotetext{
${ }^{4}$ IMF also has available data up to June 12, 2020, but data for most selected countries in this paper is not available.

${ }^{5}$ For a detailed version of measures, one should visit the IMF website.
} 
Estimated effectiveness of fiscal measures and discretionary fiscal response ratio, 2020:Q2

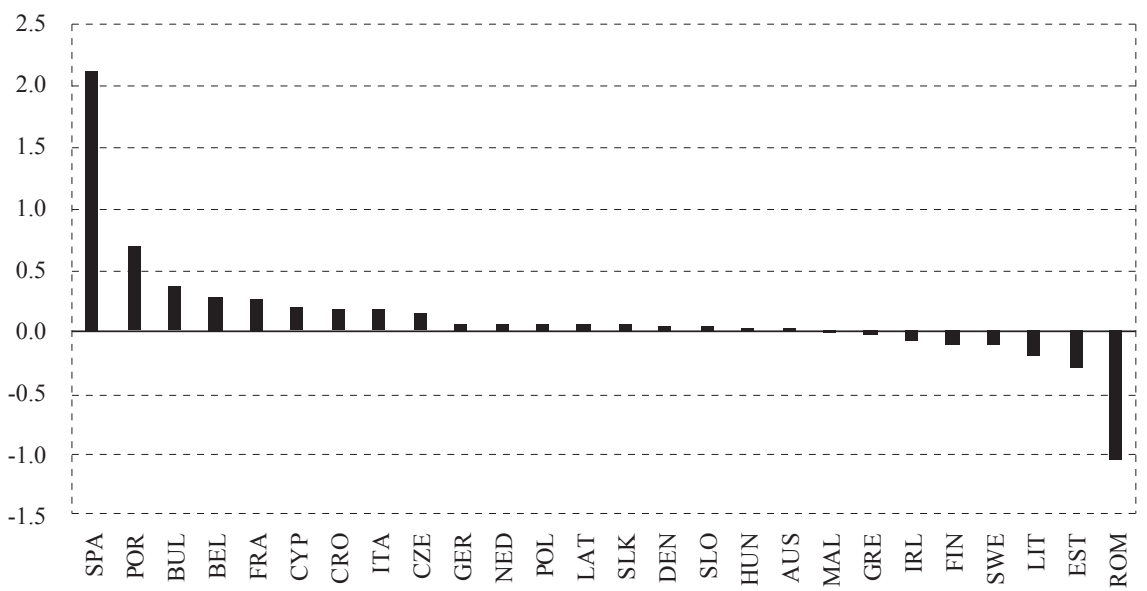

Source: Authors' own calculation based on LFS unemployment data by Eurostat (2021) and IMF (2020).

Analysis suggests that Spain had the highest ratio, which also indicates that their fiscal response got the highest returns in terms of mitigating the growth of unemployment. For one percentage point of their fiscal stimulus, they mitigate the growth of unemployment by around two percentage points. On the other hand, Romania had by far the biggest negative ratio, followed by Estonia. Furthermore, even though countries like Austria, Germany, and Slovenia had big fiscal stimulus programs, their ratio is very low, which could again indicate that size of the fiscal response is no guarantee for the successful fight against crises, even though unemployment in these countries is significantly lower and less volatile than in countries where fiscal measures seem to prevent more unemployment growth.

\subsection{LONG RUN EFFECTIVENESS OF THE COVID-19 MEASURES}

Effects of fiscal measures can be analyzed in the short run, as has just been done, and in the (mid to) long run as we do in this section. For that purpose, we present the possible implications of the fiscal measures on potential output and GDP growth from 2021 to 2023. As described earlier, we assume that all factors of production are the same in two scenarios (with and without fiscal measures). Differences in growth rates will be solely the result of estimated differences in the contribution of labor factor to potential GDP, given the different unemployment rates implied by the two scenarios. Due to limitations, as mentioned earlier in section 3.2 , in the forecasting technique and the availability of quarterly data for some variables from equations (5) and (6), we use annual data in this exercise.

The models used in this calculation are equivalent to the models used in the previous section for measuring the effectiveness of COVID-19 fiscal measures. 
Drawing on those models, we now made a forecast of the unemployment rate until 2020:Q4. After that, we transform quarterly data for unemployment into annual data by using an average of the Q1-Q4 period for each year. Using the HP filter from annual data, we estimated the natural unemployment rate for both scenarios, with (real values) and without fiscal measures (estimated values), after which we forecasted unemployment rates until 2023 in both scenarios (actual - with fiscal measures and counterfactual - without fiscal measures). Then, using equations (5) and (6), we calculated the contribution of labor to the growth of potential output every year. Finally, we compared the contributions of both scenarios for the period from 2021 to 2023 by simply summing values for the situation with fiscal measures and then deducting from it summed values of the situation without fiscal measures. Calculation ${ }^{6}$ was done by equation (6), which is based on equation (5), as follows:

$$
\sum_{t=2021}^{2023} d\left(\ln Y_{t}\right)_{\text {with measures }}-\sum_{t=2021}^{2023} d\left(\ln Y_{t}\right)_{\text {without measures }}
$$

If the difference is positive, fiscal measures have been effective and have positively impacted the growth of potential output during the forecasting horizon. On the other hand, if the difference is negative, fiscal measures have not been effective, which will have a negative effect on the growth of potential output in the future.

Figure 4 shows the cumulative difference in the labor effect on the growth of potential output between scenarios (with and without fiscal measures) for the 2021-2023 period.

\section{Figure 4}

Cumulative difference of the labor effect on the growth of potential output between scenarios with and without fiscal measures for period 2021-2023

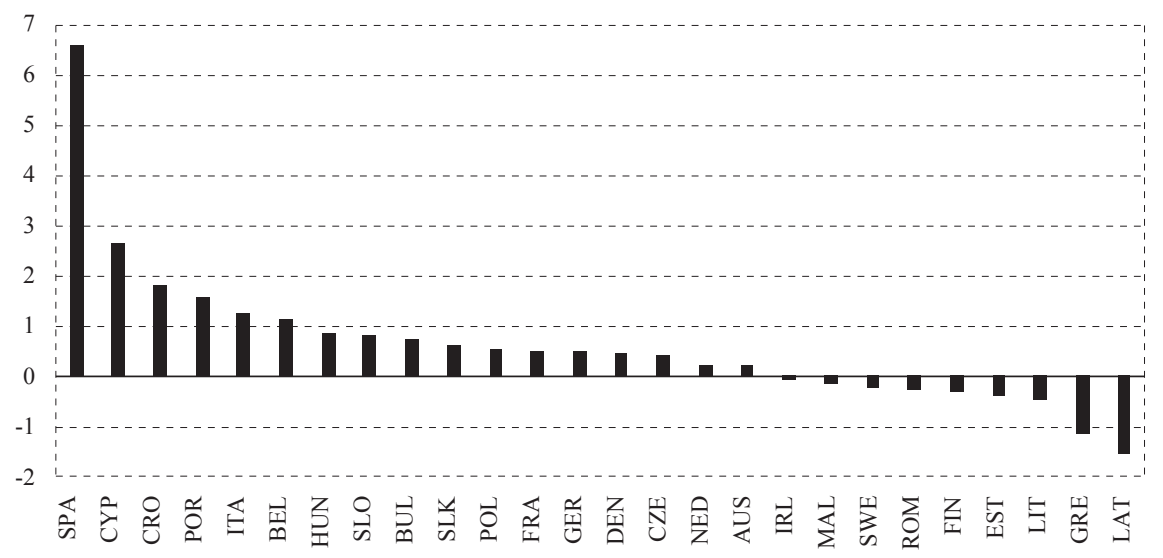

Source: Authors' own calculation based on LFS unemployment data by Eurostat (2021) and Penn World Table (Feenstra, Inklaar and Timmer, 2015).

\footnotetext{
${ }^{6}$ E.g., period 2021-2023 - With fiscal measures: 1\%, 2\%, 3\%; Without fiscal measures: -1\%, -2\%, 2\% -> Summed with fiscal measures - Summed without fiscal measures $=(1+2+3)-(-1-2+2)=7 \%$.
} 
Based on these estimates, it seems that in countries where the fiscal measures significantly mitigated labor market response, it could significantly contribute to the growth rate of potential GDP in the coming period. Furthermore, this contribution could be the largest in the Mediterranean countries. We can see those countries that depend on the tourism and service sector, like Mediterranean ones, experience much more positive long-run effects of COVID-19 fiscal measures. Also, it shows that Spain could experience the biggest positive effect on the growth of potential output, which is in line with the results of the effectiveness of COVID-19 fiscal measures in the previous section. On the other hand, estimates show that Baltic and Scandinavian countries could experience lower growth of potential output than there would be if no fiscal measures had been imposed. Although it is expected that most of the Mediterranean countries could experience a positive impact on potential output, Greece and Malta are expected to experience negative effects.

\subsection{DISCUSSION}

As discussed in the second section, the response of policymakers to the ongoing COVID-19 crisis is of great importance. The results in section 4.1 indicate that the size of the fiscal response is not of great importance. However, the structure of the fiscal response and its compliance with the economy's structure might be crucial in explaining what fiscal measures and structure of these measures there must be to prevent the adverse impacts from the COVID-19 crisis on the labor market, and thus on the economy. It can generally be concluded that countries that depend on the service sector, mainly on accommodation and food service, which in our case are Mediterranean countries, were more susceptible to COVID-19 shocks. However, although they were more prone to these shocks, their response managed to mitigate more unemployment than the others due to their economies being service-dependent. Also, this raises questions about the already known importance of diversifying the structure of the economics so that they can be more resilient to the different shocks.

The importance of the term hysteresis, or the impact of cyclical fluctuations of GDP in a crisis on the potential GDP, has also been discussed in section 2. Results in 4.2 are in line with the literature that emphasizes the existence of hysteresis effects. Thus, the results indicate the presence of hysteresis, in other words, that cyclical fluctuations of the GDP in the ongoing COVID-19 crisis could have a negative and permanent effect on the growth of the potential GDP if the policymakers undertake no fiscal measures. Furthermore, it can be concluded that the Mediterranean countries experience a positive and more significant effect of preventing the rise in unemployment rates than other countries. In other words, they would have experienced significantly higher growth in the unemployment rate if no fiscal measures had been imposed. In addition, these are countries where unemployment rates are usually relatively high and often persistent, making fiscal measures extremely important for reducing the short-, but also and long-term economic costs of the pandemic. According to that, the contribution of labor to the projected growth of the potential GDP is greater in Mediterranean countries than others in our sample. Due to different contributions of labor in the economies of 
different countries, the growth of potential output reacts differently to fiscal measures imposed. Nevertheless, it must be emphasized that although the economies of Mediterranean countries have similar structures with tourism and the service-sector having an important role, not all experienced such positive effects, with Greece and Malta standing out from peer countries. Even though the tourism and service sectors are highly important for Malta, the biggest share of their GDP (272\% in 2020) is influenced by foreign trade, which was hardly affected by the COVID-19 crisis. When talking about Greece, the effectiveness of imposed fiscal measures could be influenced by the previous economic situation in Greece, more precisely by recovery from long-lasting recession and the migration crisis.

Our recommendation to policymakers in times of crisis is that inadequate fiscal support does not only lead to negative effects in the short-term, but also tends to be a problem for the future development of the economy, the potential of which can be harmed. All of that can lower the short- and long-term well-being of citizens. Literature suggests that a crisis increases the long-term unemployment rate (Kroft et al., 2014) and that it plays a crucial role in the existence of hysteresis in the labor market (Ball, 2014). Keeping that in mind, a fiscal reaction in this crisis and its estimated effects could lead to lesser short- and long-term costs of this crisis. Furthermore, we emphasize that a bigger fiscal stimulus does not guarantee better results; one should rather pay more attention to the structure of the fiscal response and its compliance with the structure of the economy, but further research on this topic is needed. Thus, an adequate fiscal stimulus could lead to higher growth of GDP and potential GDP, which would consequently lead to lower and more sustainable levels of budget deficits and public debt.

The limitation of this paper comes from its use of aggregate levels of discretionary fiscal policy measures due to the limitation of available data at the time of writing. The problems with this measure are that the responses vary according to country-specific circumstances, for example, the number of cases of infection. Furthermore, the problem of lack of information exists in the labor market. We do not have information on the details of policies aimed at keeping the unemployment rate low. For example, some countries adopted more flexible approaches by providing social transfers to newly unemployed persons instead of maintaining the unemployment rate by supporting firms that retain workers. Finally, we do not have information on the structure of fiscal support - the question arises as to what proportion of fiscal expenditure was directed at maintaining the employment rate. For future research, one might want to use disaggregate measures of the undertaken discretionary fiscal policy. ${ }^{7}$

Also, there is a need to test the robustness of the results additionally. Okun's law in some countries fits the data better than in others, but we do not distinguish between them. Furthermore, it is practically impossible to separate the supply-side shocks

\footnotetext{
${ }^{7}$ We would like to thank our anonymous reviewer for this paragraph, which is a major contribution to the better positioning of our results in this paper as first approximations. With newly available data, new approximations will be clearer to approximate and connect with existing approximations in this paper.
} 
from the demand-side shocks of COVID-19 at this point. We are aware of this problem; however, its consequences for our analysis are beyond the scope of this paper, and we are focusing on short-term and long-term impact assessment using standard methods, which do not necessarily lead to adequate estimates of the trend (potential), or the cyclical components (either in the case of the unemployment rate or the total output (GDP)).

\section{CONCLUSION}

This paper aimed to examine the effectiveness of the fiscal measures undertaken by the policymakers to the response to the COVID-19 crisis in the analyzed EU countries. Firstly, the short-term effects of the fiscal measures were examined in the analyzed countries. To assess the effectiveness, we have used the trend-cyclical unemployment rate as a benchmark for the effect of the COVID-19 on the economies. We have used Okun's law to estimate and forecast unemployment rates, and then we have compared forecasted values with the actual values of the unemployment rates. Results indicate that the undertaken fiscal measures in the second quarter of 2020 were successful in most EU-26 countries, except in Malta, Greece, Finland, Ireland, Sweden, Lithuania, Estonia, and Romania. In addition, the effect was relatively smaller in the first quarter of 2020 since the COVID-19 crisis in some countries did not occur at the time.

Secondly, we have examined how the familiar labor market hysteresis effect makes these fiscal measures important not only in the short but also in the long run, using the concept of potential output. Our results are in line with the literature that confirms the existence of the hysteresis effects. Namely, in most countries, the estimated growth rate of potential GDP is significantly higher in the actual scenario in which fiscal measures have been implemented than in the counterfactual scenario in which we assume that these fiscal measures have not been implemented.

Furthermore, it can be concluded that most of the Mediterranean countries have experienced a positive effect, more significant in preventing the rise in unemployment rates than other analyzed countries. On the other hand, estimations indicate that Baltic countries did not benefit from imposed fiscal measures. Nevertheless, more successful prevention in the rise of the unemployment rates does not necessarily lead to greater growth of the potential GDP driven by labor due to the different contributions of labor in different economies.

In line with results from this paper, we conclude that inadequate fiscal support can have negative short- and long-term effects on the economy's growth and that adequate fiscal support (was and still) needs to be implemented to fight the current crisis and achieve short- and long-term prosperity.

\section{Disclosure statement}

The authors state that they do not have any financial or other substantive conflict of interest. 
1. Anderton, R. [et al.], 2014. Disaggregating Okun's Law: Decomposing the Impact of the Expenditure Components of GDP on Euro Area Unemployment. ECB Working Paper, No. 1747.

2. Ball, L., 2014. Long-term damage from the Great Recession in OECD countries. European Journal of Economics and Economic Policies: Intervention, 11(2), pp. 149-160. https://doi.org/10.4337/ejeep.2014.02.02

3. Ball, L., Leigh, D. and Loungani, P., 2013. Okun's law: fit at 50? NBER Working Paper, No. 18668. https://doi.org/10.3386/w18668

4. Barrios, S., Strobl, E. and Bertinelli, L., 2010. Trends in Rainfall and Economic Growth in Africa: A Neglected Cause of the African Growth Tragedy. Review of Economics and Statistics, 92(2), pp. 350-366. https://doi.org/10.1162 /rest.2010.11212

5. Barro, R. J., Urs'ua, J. F. and Weng, J., 2020. The Coronavirus and the Great Influenza Pandemic: Lessons from the "Spanish Flu" for the Coronavirus's Potential Effects on Mortality and Economic Activity. NBER Working Paper, No. 26866. https://doi.org/10.3386/w26866

6. Bell, L. M., 2009. Hysteresis in Unemployment: Old and New Evidence. NBER Working Paper, No. 14818. https://doi.org/10.3386/w14818

7. Benedetti, F. C., Sedláček, P. and Sterk, V., 2020. EU start-up calculator: impact of COVID-19 on aggregate employment: Scenario analysis for Denmark, Estonia, Finland, France, Latvia, Lithuania, Portugal and Sweden. Luxembourg: Publications Office of the European Union. http://dx.doi.org/ $10.2760 / 232741$

8. Bentolila, S., García-Pérez, I. J. and Jansen, M., 2017. Are the Spanish longterm unemployed unemployable? SERIES, 8, pp. 1-41. https://doi.org/10.1007/ s13209-017-0155-z

9. Blanchard, O. J. and Summers, L. H., 1986. Hysteresis and the European Unemployment Problem. NBER Macroeconomics Annual, 1, pp. 15-78. https://doi.org/10.1086/654013

10. Blanchard, O. J., 1991. Wage Bargaining and Unemployment Persistence. Journal of Money, Credit and Banking, 23(3), pp. 277-292. https://doi.org/10. 2307/1992746

11. Blanchard, O., Cerutti, E. and Summers, L., 2015. Inflation and Activity - Two Explorations and their Monetary Policy Implications. IMF Working Papers, 15(230). https://doi.org/10.5089/9781513536613.001

12. Bloom, D. E. [et al.], 1998. Geography, Demography, and Economic Growth in Africa. Brookings Papers on Economic Activity, (2), pp. 207-295. https:// doi.org/10.2307/2534695

13. Bloom, N., 2009. The Impact of Uncertainty Shocks. Econometrica: Journal of the Econometric Society, 77(3), pp. 623-685. https://doi.org/10.3982/ECTA6248

14. Bodnár, K. [et al.], 2020. The impact of COVID-19 on potential output in the euro area. Economic Bulletin, (7). 
15. Brauner, J. M. [et al.], 2021. Inferring the effectiveness of government interventions against COVID-19. Science, 371(6531). https://doi.org/10.1126/science. abd9338

16. Campbell, J. Y. and Mankiw, N., 1989. International evidence on the persistence of economic fluctuations. Journal of Monetary Economics, 23(2), pp. 319-333. https://doi.org/10.1016/0304-3932(89)90054-8

17. Cerra, V. and Saxena, S. C., 2008. Growth Dynamics: The Myth of Economic Recovery. American Economic Review, 98(1), pp. 439-457. https://doi.org/10. 1257/aer.98.1.439

18. Cerra, V. and Saxena, S. C., 2017. Booms, Crises, and Recoveries: A New Paradigm of the Business Cycle and its Policy Implications. IMF Working Papers, WP 17/250. https://doi.org/10.5089/9781484325759.001

19. Cerra, V., Panizza, U. and Saxena, S. C., 2012. International Evidence on Recovery from Recessions. Contemporary Economic Policy, 31(2), pp. 424439. https://doi.org/10.1111/j.1465-7287.2012.00313.x

20. Cohen, D. S., 2000. A Quantitative Defense of Stabilization Policy. Finance and Economics Discussion Series, No. 34. https://doi.org/10.17016/FEDS.2000.34

21. DeLong, J. B. and Summers, L., 2012. Fiscal Policy in a Depressed Economy. Brookings Papers on Economic Activity, 43(1), pp. 233-297. https://doi.org/10. 1353/eca.2012.0000

22. Di Tella, R. and MacCulloch, R., 2006. Europe vs America: Institutional hysteresis in a Simple Normative Model. Journal of Public Economics, 90(12), pp. 2161-2186. https://doi.org/10.1016/j.jpubeco.2006.05.013

23. Dupraz, S., Nakamura, E. and Steinsson, J., 2019. A Plucking Model of Business Cycles. NBER Working Paper, No. 26351. https://doi.org/10.3386/w26351

24. Economou, A. and Psarianos, I. N., 2016. Revisiting Okun's Law in European Union countries. Journal of Economic Studies, 43(2), pp. 275-287. https://doi. org/10.1108/JES-05-2013-0063

25. Eurostat, 2021. Eurostat: Unemployment by sex and age (1992-2020) - quarterly data. Eurostat.

26. Fatas, A. and Summers, H. L., 2018. The permanent effects of fiscal consolidations. Journal of International Economics, 112, pp. 238-250. https://doi. org/10.1016/j.jinteco.2017.11.007

27. Feenstra, R., Inklaar, R. and Timmer, M., 2015. The Next Generation of the Penn World Table. American Economic Review, 105(10), pp. 3150-3182. https://doi.org/10.1257/aer.20130954

28. Fornaro, L. and Wolf, M., 2020. Covid-19 Coronavirus and Macroeconomic Policy. Barcelona Graduate School of Economics Working Paper, No. 1168.

29. Gechert, S., Horn, G. and Paetz, C., 2019. Long-term Effects of Fiscal Stimulus and Austerity in Europe. Oxford Bulletin of Economics and Statistics, 81(3), pp. 647-666. https://doi.org/10.1111/obes.12287

30. Gonzales-Castillo, J. R. [et al.], 2020. COVID-19 pandemic and Public Health Policies in Peru: March-May 2020. Rev. salud pública, 22(2). https://doi.org/ 10.15446/rsap.v22n2.87373 
31. Gozgor, G., 2013. Testing Unemployment Persistence in Central and Eastern European Countries. International Journal of Economics and Financial Issues, 3(3), pp. 694-700.

32. Haltmaier, J., 2013. Do Recessions Affect Potential Output? FRB International Finance Discussion Paper, No. 1066. https://doi.org/10.2139/ssrn.2251879

33. Heimberger, P., 2020. Potential Output, EU Fiscal Surveillance and the COVID-19 Shock. Intereconomics, Review of European Economic Policy, 55, pp. 167-174. https://doi.org/10.1007/s10272-020-0895-z

34. Hershbein, B. and Stuart, B. A., 2020. Recessions and local labor market hysteresis. Upjohn Institute Working Paper, No. 20-325. https://doi.org/10.17848/ wp20-325

35. IMF, 2009. What's the Damage? Medium-Term Output Dynamics after Financial Crises. World Economic Outlook, Ch. 4. https://doi.org/10.5089/978158 9068070.081

36. IMF, 2020. Database of fiscal policy reponses to COVID-19: October 2020 database. Washington: IMF.

37. IMF, 2021. Policy Reponses to COVID-19 - Policy Tracker. Washington: IMF.

38. Jord'a, O., Singh, S. R. and Taylor, A. M., 2020. Longer-Run Economic Consequences of Pandemics. Federal Reserve Bank of San Francisco Working Paper, No. 2020-09. https://doi.org/10.24148/wp2020-09

39. Jovičić, G., 2017. Procjena potencijalnog rasta i jaza BDP-a u Hrvatskoj. Pregledi Hrvatske narodne banke, P-38.

40. King, R. and Rebelo, S., 1988. Business Cycles with Endogenous Growth. University of Rochester Working Paper.

41. King, R. G., Plosser, C. I. and Rebelo, S. T., 1988. Production, growth and business cycles: II. New Directions. Journal of Monetary Economics, 21(2-3), pp. 309-341. https://doi.org/10.1016/0304-3932(88)90034-7

42. Knotek, E. S., 2007. How useful is Okun's law? Economic Review, 92(Q IV), pp. 73-103.

43. Kroft, K. [et al.], 2014. Long-term unemployment and the Great Recession: The role of composition, duration dependence, and non-participation. NBER Working Paper, No. 20273. https://doi.org/10.3386/w20273

44. Loageay, C. and Tober, S., 2005. Hysteresis and NAIRU in the Euro Area. Macroeconomic Policy Institute Working Paper, No. 4. https://doi.org/10.1111/ j.1467-9485.2006.00387.x

45. Ma, C., Rogers, J. and Xhou, S., 2020. Modern Pandemics: Recession and Recovery: manuscript. https://doi.org/10.2139/ssrn.3668472

46. Nelson, C. R. and Plosser, C. R., 1982. Trends and random walks in macroeconmic time series: Some evidence and implications. Journal of Monetary Economics, 10(2), pp. 139-162. https://doi.org/10.1016/0304-3932(82)90012-5

47. Okun, A., 1962. Potential GNP: Its Measurement and Significance. Proceedings of the Business and Economics Section of the American Statistical Association, pp. 98-104. 
48. Rawdanowiczi, Ł. [et al.[, 2014. Secular Stagnation: Evidence and Implications for Economic Policy. OECD Economics Department Working Papers, No. 1169. https://doi.org/10.1787/5jxvgg6q27vd-en

49. Reifschneider, D., Wascher, W. and Wilcox, D., 2015. Aggregate Supply in the United States: Recent Developments and Implications for the Conduct of Monetary Policy. IMF Economic Review, 63(1), pp. 71-109. https://doi. org/10.1057/imfer.2015.1

50. Reinhart, C. M. and Rogoff, K. S., 2009. The Aftermath of Financial Crises. American Economic Review, 99(2), pp. 466-472. https://doi.org/10.1257/aer. 99.2.466

51. Stadler, G. W., 1986. Real versus monetary business cycle theory and the statistical characteristics of output fluctuations. Economics Letters, 22(1), pp. 51-54. https://doi.org/10.1016/0165-1765(86)90141-2

52. Stadler, G. W., 1990. Business Cycle Models with Endogenous Technology. American Economic Review, 80(4), pp. 763-778.

53. Stiglitz, J. E., 1993. Endogenous Growth and Cycles. NBER Working Paper, No. 4286. https://doi.org/10.3386/w4286

54. Stock, J. H. and Watson, M. W., 2011. Introduction to Econometrics. 3. ed. London: Pearson.

55. Stockhammar, P. and Oller, L.-E., 2012. A Simple Heteroscedasticity Removing Filter. Communication in Statistics - Theory and Methods, 41(2), pp. 281299. https://doi.org/10.1080/03610926.2010.521289

56. Yoo, S. and Managi, S., 2020. Global mortality benefits of COVID-19 action. Technological Forecasting and Social Change, 160. https://doi.org/10.1016/j. techfore.2020.120231

57. WHO, 2021. Coronavirus disease (COVID-19) pandemic. 
Appendix A presents estimated results of Okun's law in selected European countries. OLS estimation presents equation (1) with GDP at time $t$, and lagged values of GDP at time $t-1$ and $t-2$. OLS_noautocorrelation presents estimation of equation (1) with GDP at time $t$, and lagged values of GDP at time $t-1$ and $t-2$, and with lagged values of change in the unemployment rate in time $t-1$ and/or $t-2$, depending on the autocorrelation problem. Also, if the problem of autocorrelation was present even after adding more than two lags of the dependent variable, GARCH $(1,1)$ model was used to solve it. OLS_nohetero refers to estimated equation (1) that is the same as the OLS_noautocorrelation, but in this case, GARCH $(1,1)$ model is used to solve the problem heteroskedasticity if present. Lastly, dU presents the actual change in the unemployment rate. Suppose estimated values of the change in the unemployment rate are higher than the actual values of the change in the unemployment rate. In that case, this indicates the effectiveness of fiscal policy measures undertaken in the COVID-19 crisis.

\section{Figure A1}

Okun's law in Austria

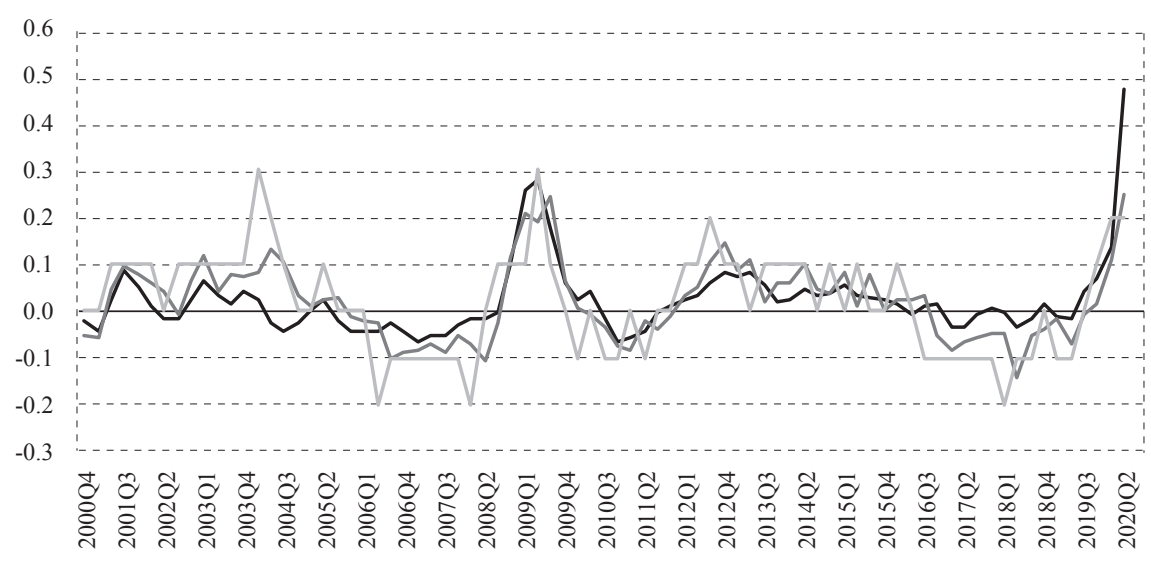

- OLS - OLS_noautocorrelation $\longrightarrow \mathrm{dU}$

Source: Authors'own calculation based on Labor force survey (LFS) unemployment data by Eurostat (2021). 


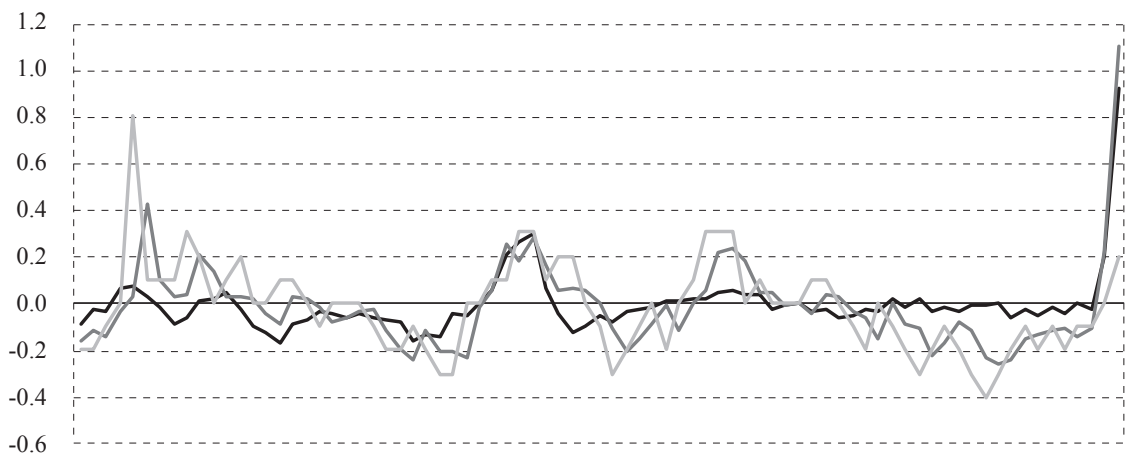

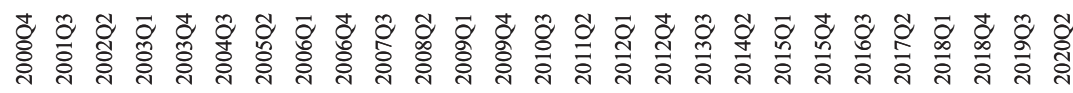
OLS

OLS noautocorrelation $\mathrm{dU}$

Source: Authors' own calculation based on Labor force survey (LFS) unemployment data by Eurostat (2021).

\section{Figure A3}

Okun's law in Bulgaria

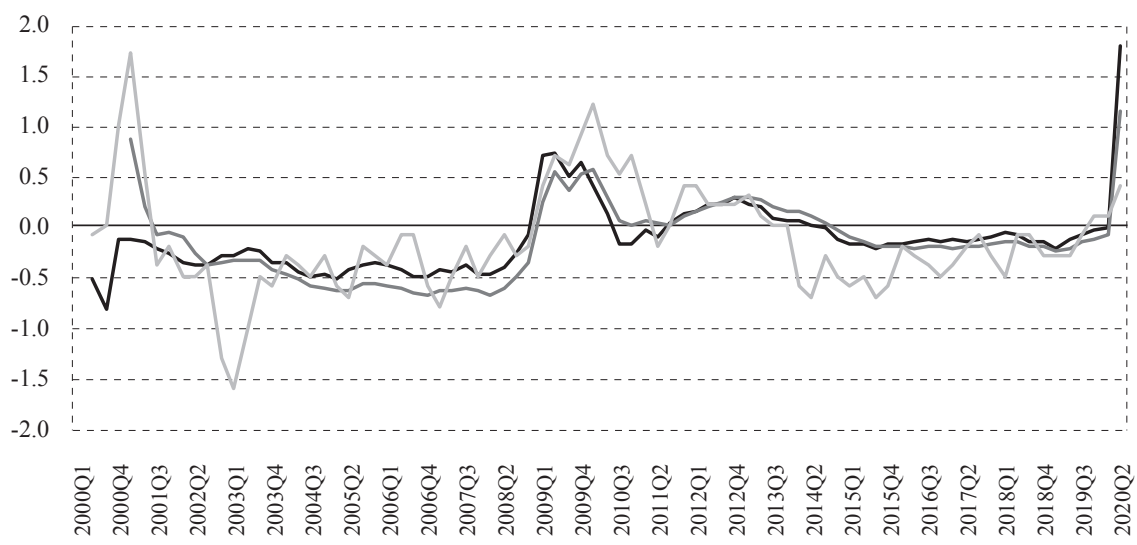

OLS OLS_noautocorrelation $\longrightarrow \mathrm{dU}$

Source: Authors' own calculation based on Labor force survey (LFS) unemployment data by Eurostat (2021). 
Figure A4

Okun's law in Croatia

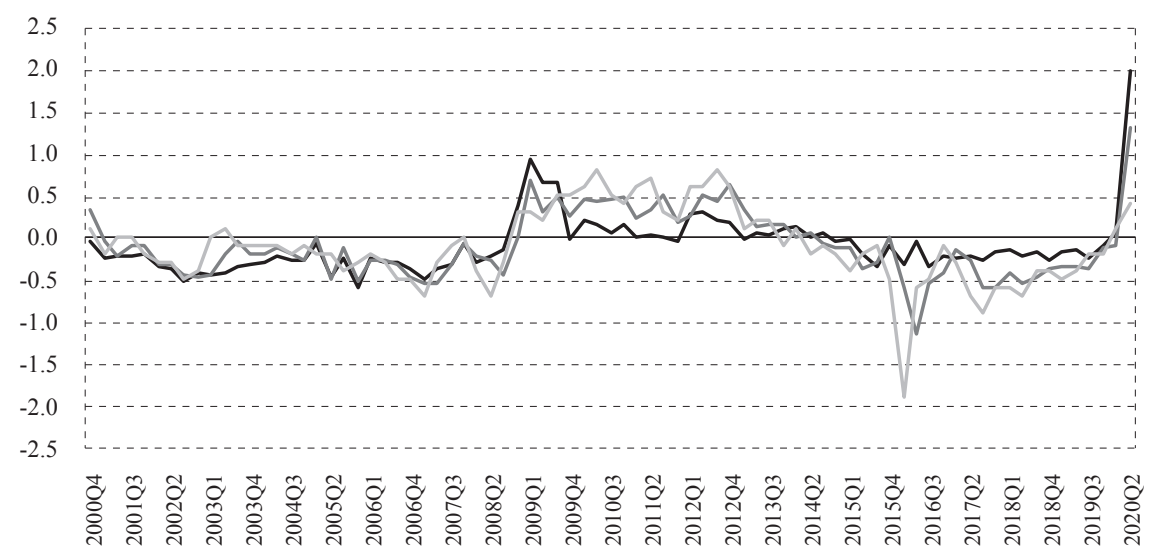

OLS

OLS_noautocorrelation

$\mathrm{dU}$

Source: Authors' own calculation based on Labor force survey (LFS) unemployment data by Eurostat (2021).

\section{Figure A5}

Okun's law in Cyprus

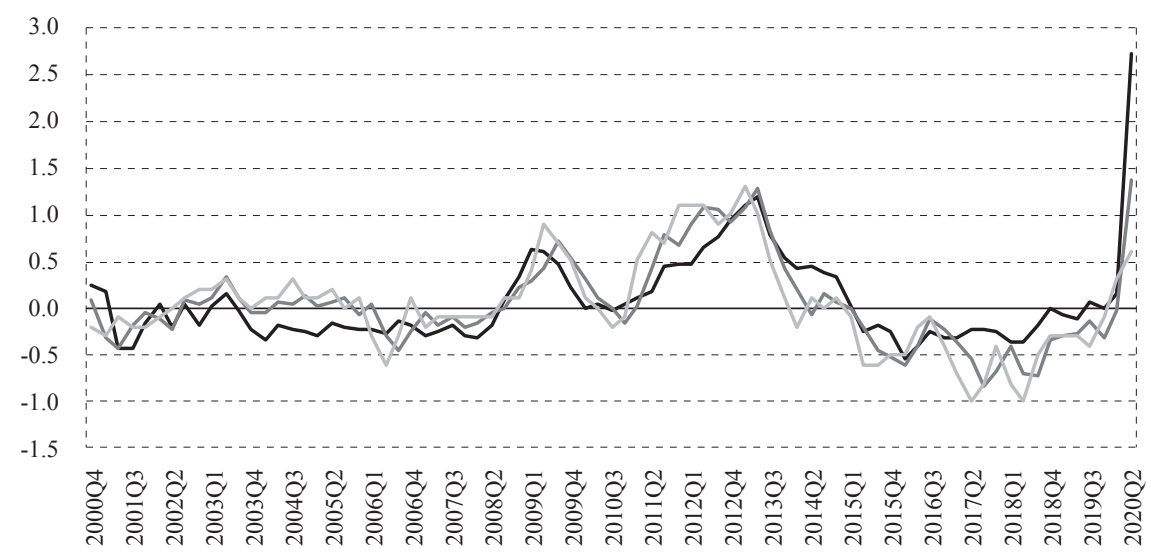

OLS - OLS_noautocorrelation $\longrightarrow \mathrm{dU}$

Source: Authors' own calculation based on Labor force survey (LFS) unemployment data by Eurostat (2021). 
Okun's law in Czechia

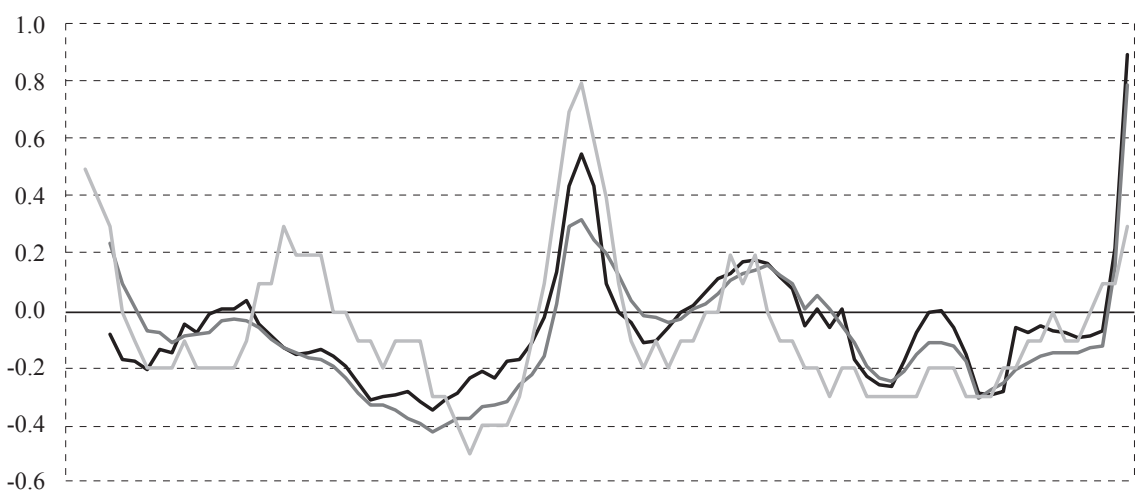

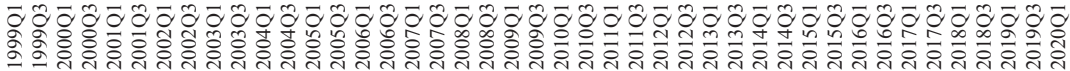

- OLS - OLS_noautocorrelation $\longrightarrow \mathrm{dU}$

Source: Authors' own calculation based on Labor force survey (LFS) unemployment data by Eurostat (2021).

\section{Figure A7}

Okun's law in Denmark

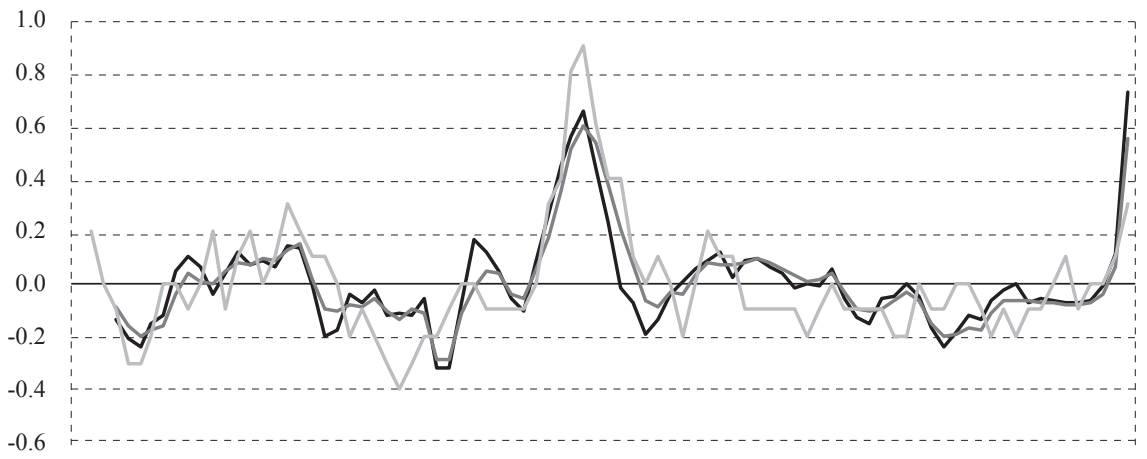

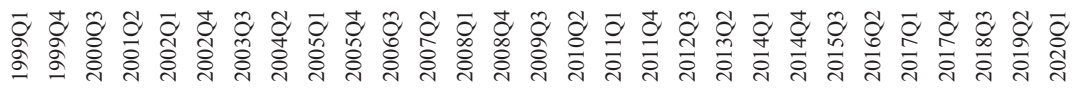
- OLS OLS_noautocorrelation $\mathrm{dU}$

Source: Authors'own calculation based on Labor force survey (LFS) unemployment data by Eurostat (2021). 
Figure A8

Okun's law in Estonia

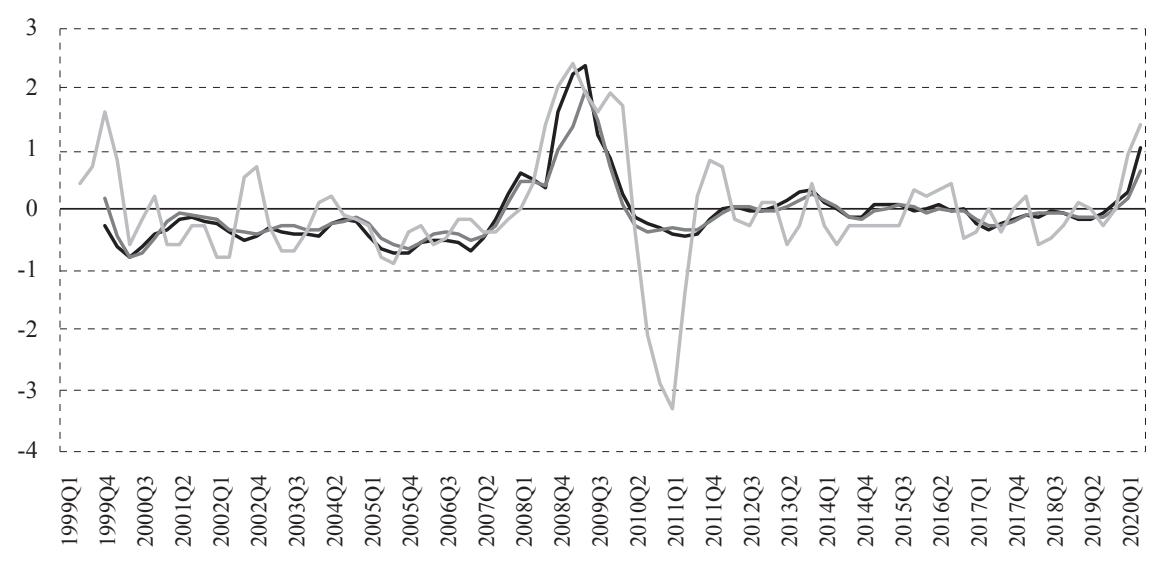

Source: Authors' own calculation based on Labor force survey (LFS) unemployment data by Eurostat (2021).

\section{Figure A9}

\section{Okun's law in Finland}

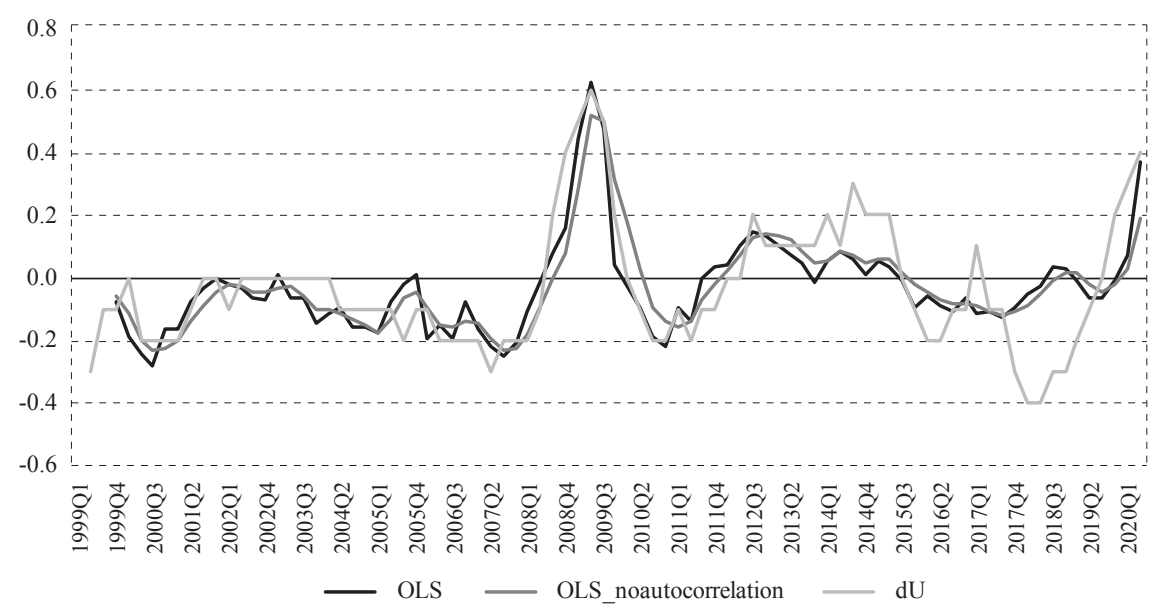

Source: Authors' own calculation based on Labor force survey (LFS) unemployment data by Eurostat (2021). 
Figure A10

Okun's law in France

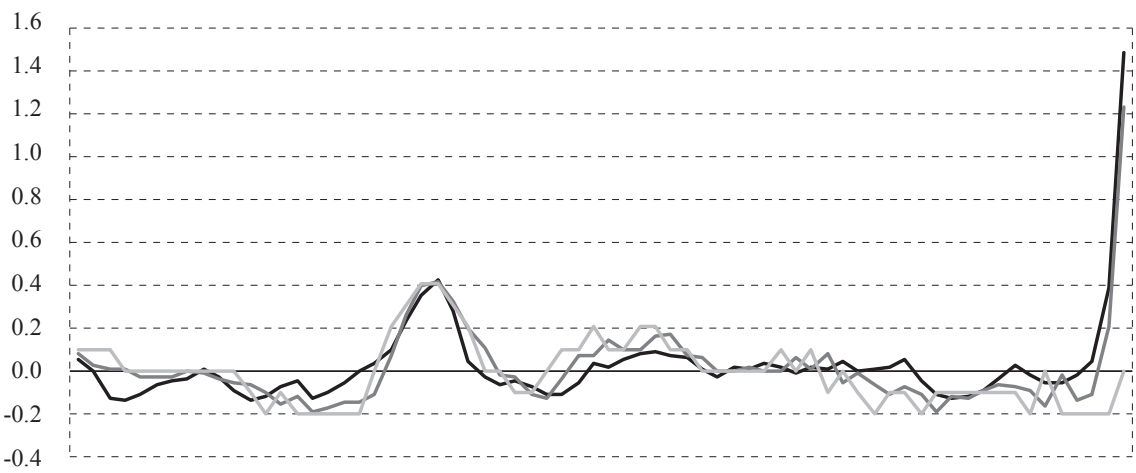

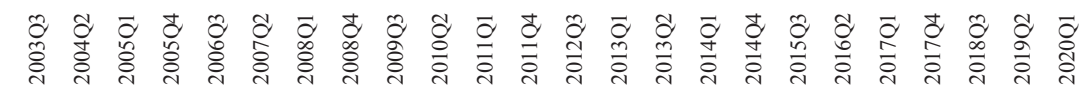

- OLS - OLS_noautocorrelation $\longrightarrow \mathrm{dU}$

Source: Authors' own calculation based on Labor force survey (LFS) unemployment data by Eurostat (2021).

\section{Figure A11}

Okun's law in Germany

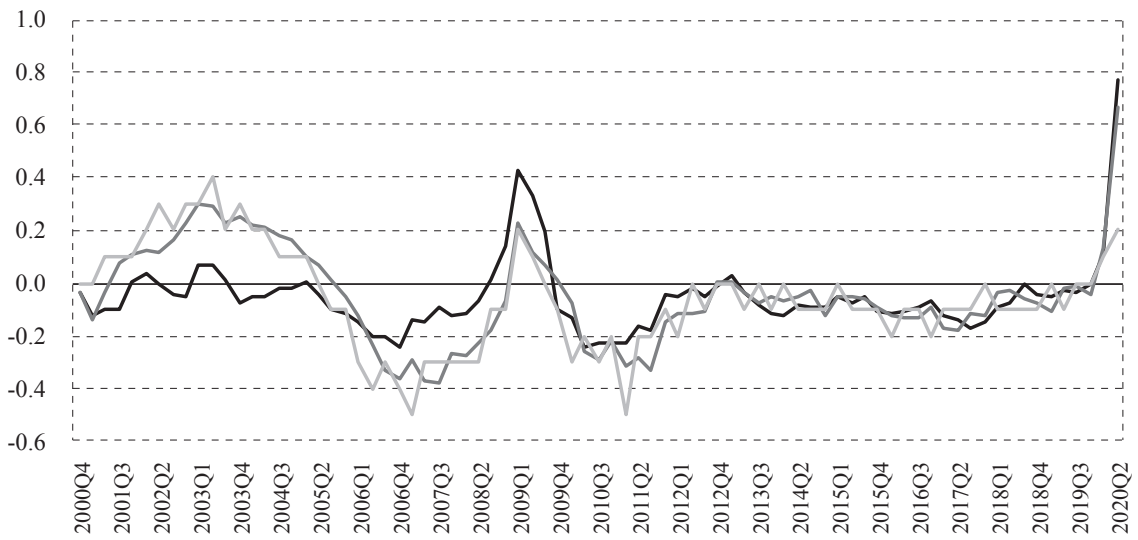

OLS

OLS_noautocorrelation

dU

Source: Authors' own calculation based on Labor force survey (LFS) unemployment data by Eurostat (2021). 
Figure A12

Okun's law in Greece

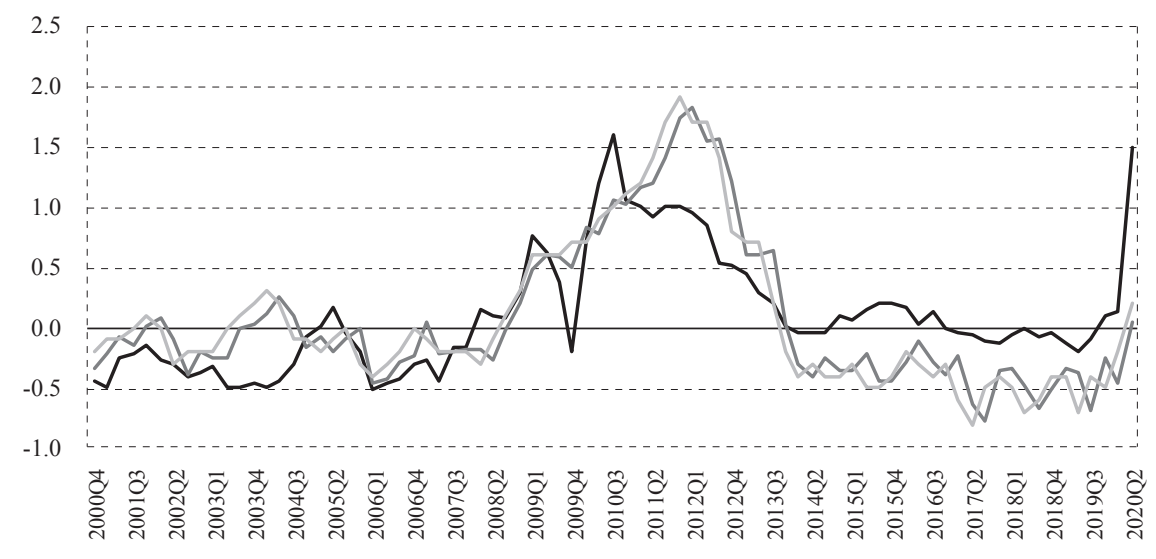

- OLS $\longrightarrow$ OLS_noautocorrelation $\longrightarrow \mathrm{dU}$

Source: Authors' own calculation based on Labor force survey (LFS) unemployment data by Eurostat (2021).

\section{Figure A13}

Okun's law in Hungary

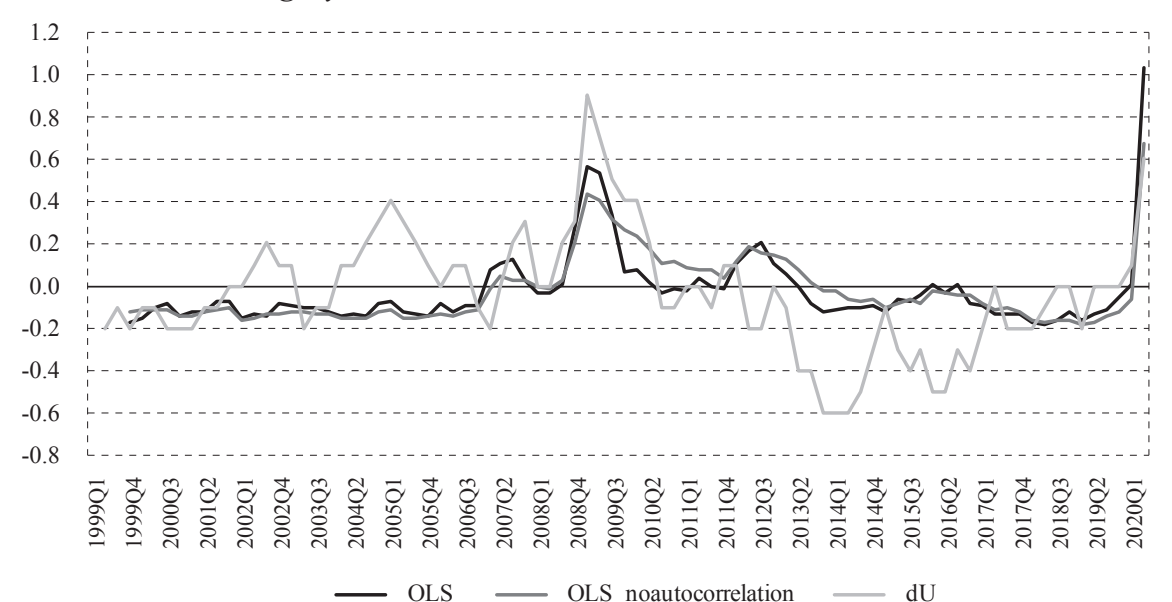

Source: Authors'own calculation based on Labor force survey (LFS) unemployment data by Eurostat (2021). 


\section{Figure A14}

Okun's law in Ireland
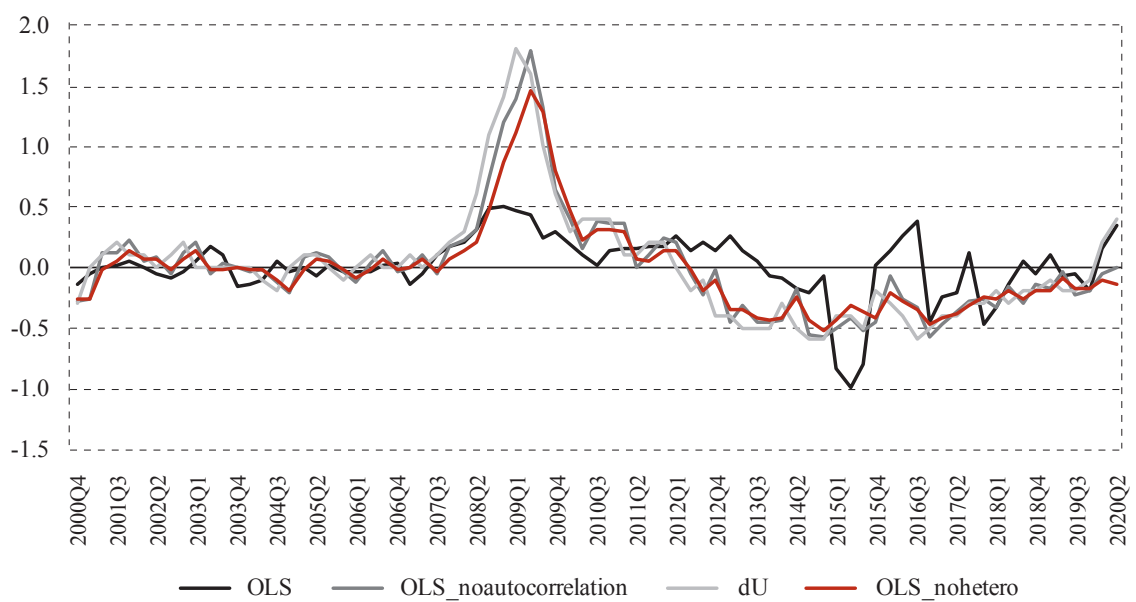

Source: Authors' own calculation based on Labor force survey (LFS) unemployment data by Eurostat (2021).

\section{Figure A15}

Okun's law in Italy

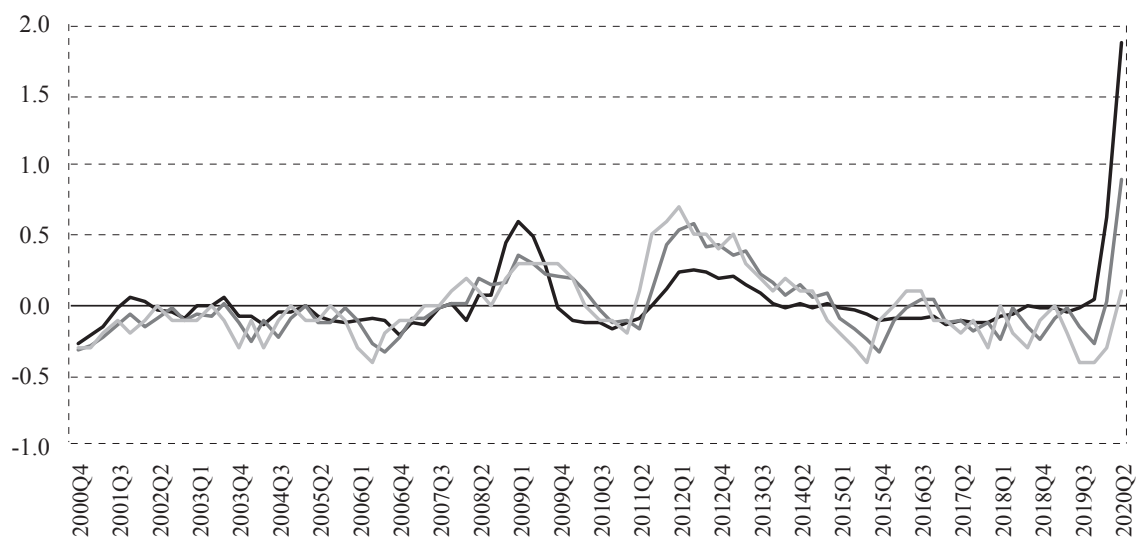

— OLS - OLS_noautocorrelation $\mathrm{dU}$

Source: Authors' own calculation based on Labor force survey (LFS) unemployment data by Eurostat (2021). 
Figure A16

Okun's law in Latvia

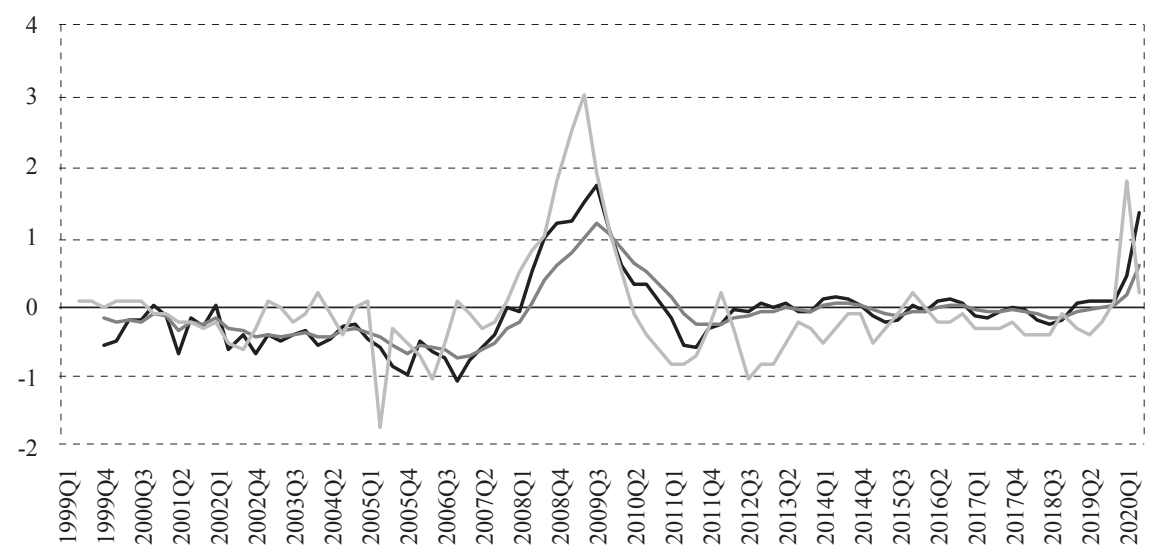

OLS - OLS_noautocorrelation $\longrightarrow \mathrm{dU}$

Source: Authors' own calculation based on Labor force survey (LFS) unemployment data by Eurostat (2021).

\section{Figure A17}

\section{Okun's law in Lithuania}

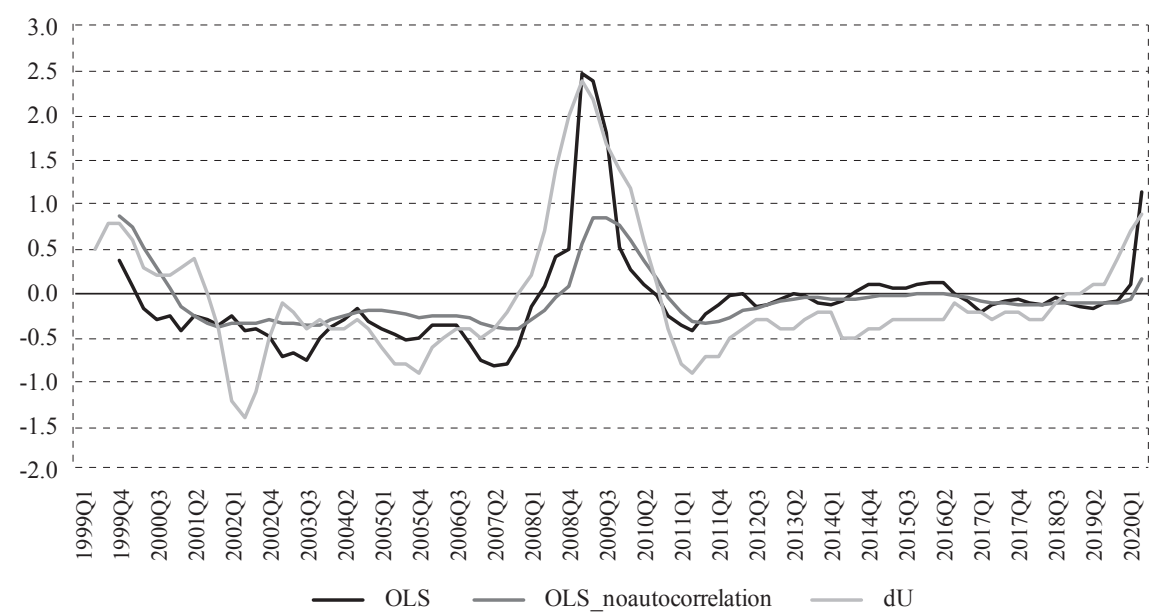

Source: Authors' own calculation based on Labor force survey (LFS) unemployment data by Eurostat (2021). 
Figure A18

Okun's law in Malta

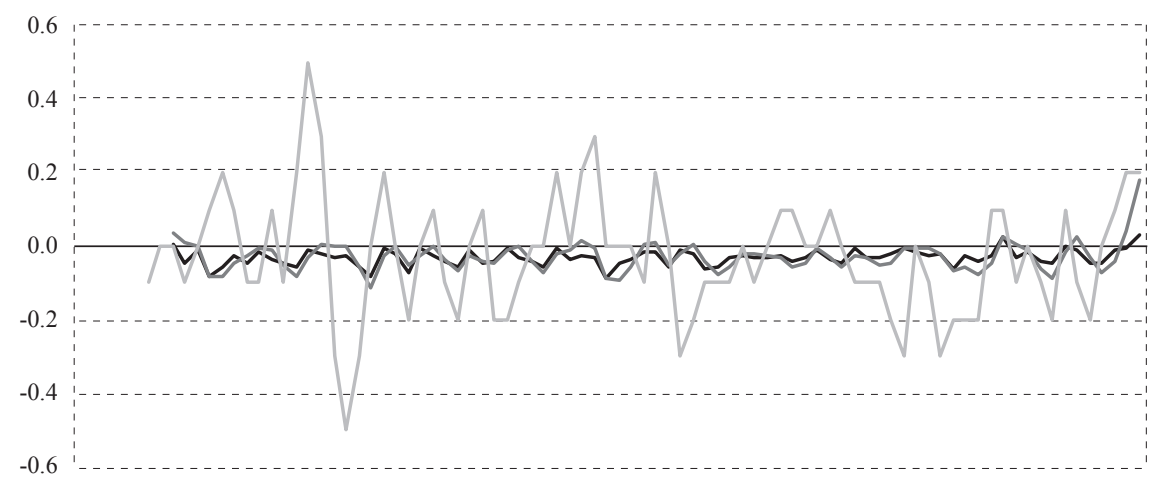

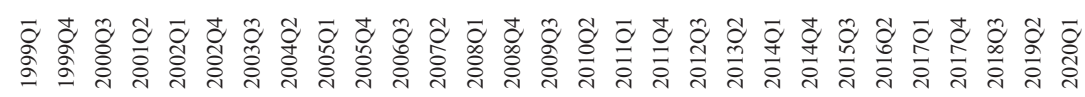

OLS

OLS_noautocorrelation

dU

Source: Authors' own calculation based on Labor force survey (LFS) unemployment data by Eurostat (2021).

\section{Figure A19}

Okun's law in Netherlands

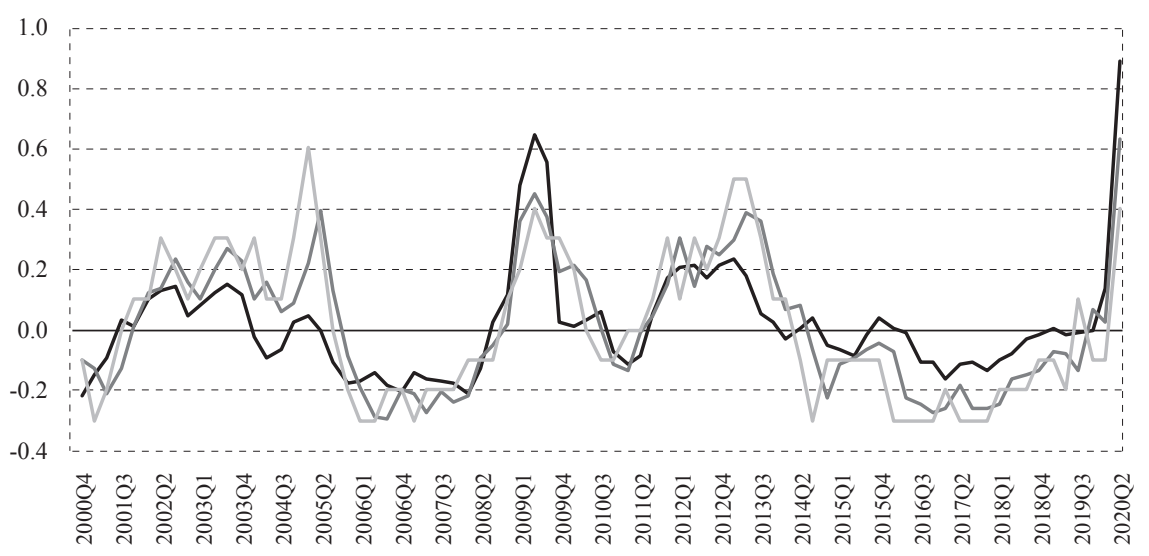

- OLS OLS noautocorrelation

$\mathrm{dU}$

Source: Authors' own calculation based on Labor force survey (LFS) unemployment data by Eurostat (2021). 
Figure A20

Okun's law in Poland

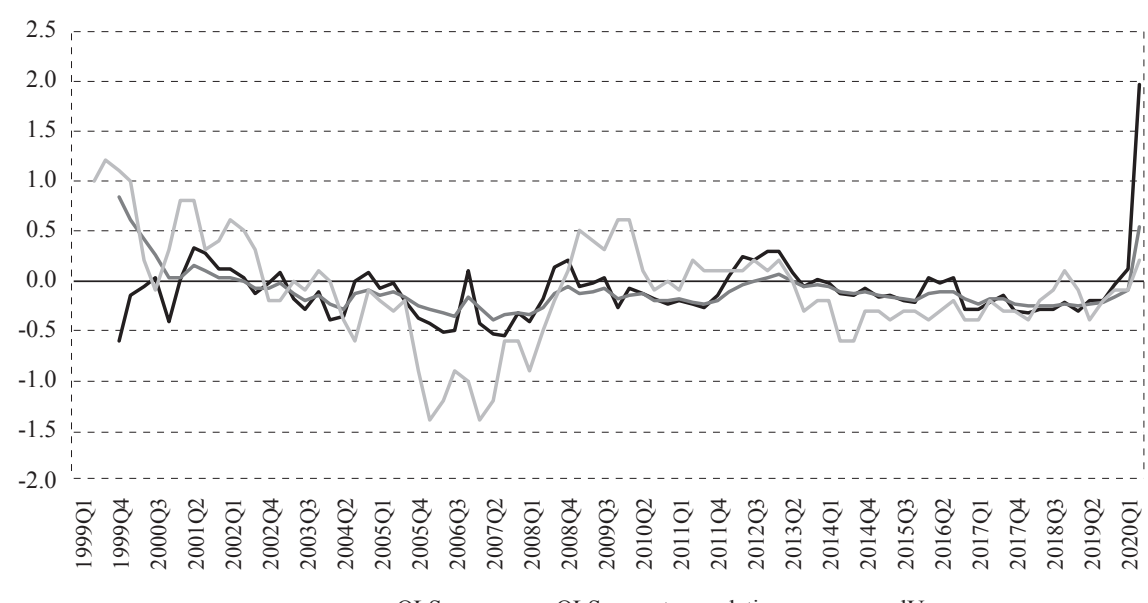

Source: Authors' own calculation based on Labor force survey (LFS) unemployment data by Eurostat (2021).

\section{Figure A21}

Okun's law in Portugal

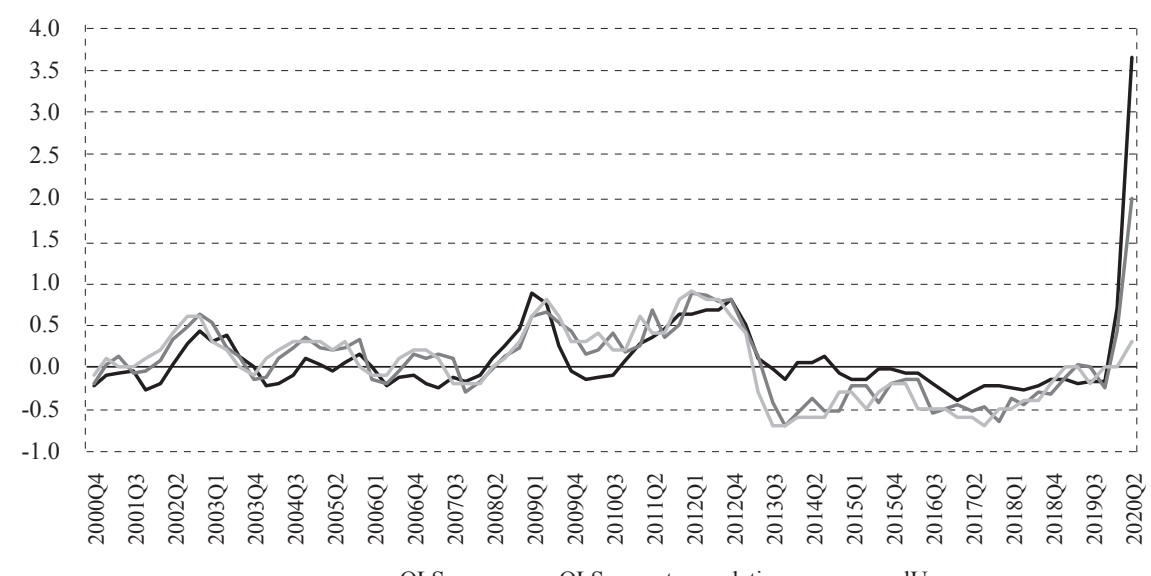

Source: Authors' own calculation based on Labor force survey (LFS) unemployment data by Eurostat (2021). 
Figure A22

\section{Okun's law in Romania}

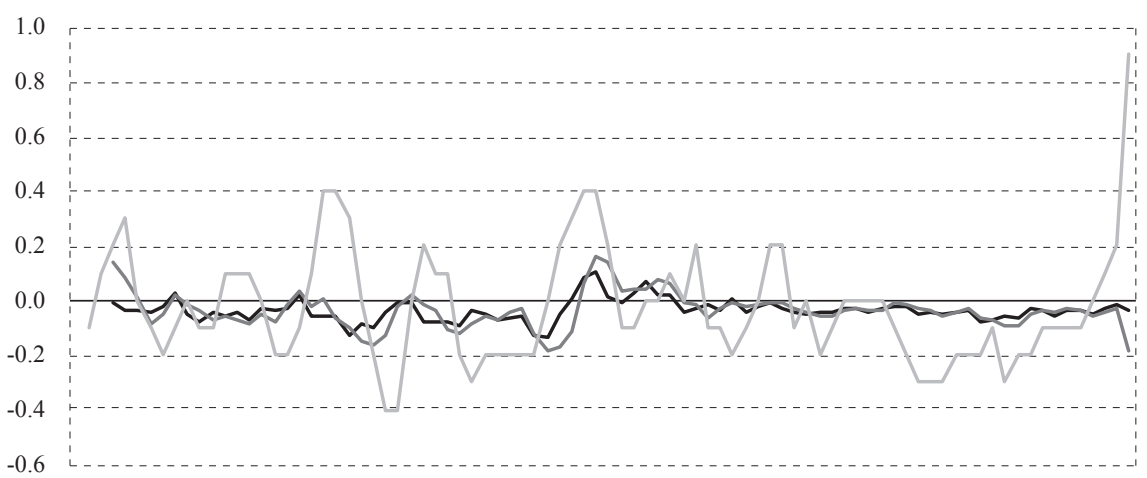

Source: Authors' own calculation based on Labor force survey (LFS) unemployment data by Eurostat (2021).

\section{Figure A23}

Okun's law in Slovakia

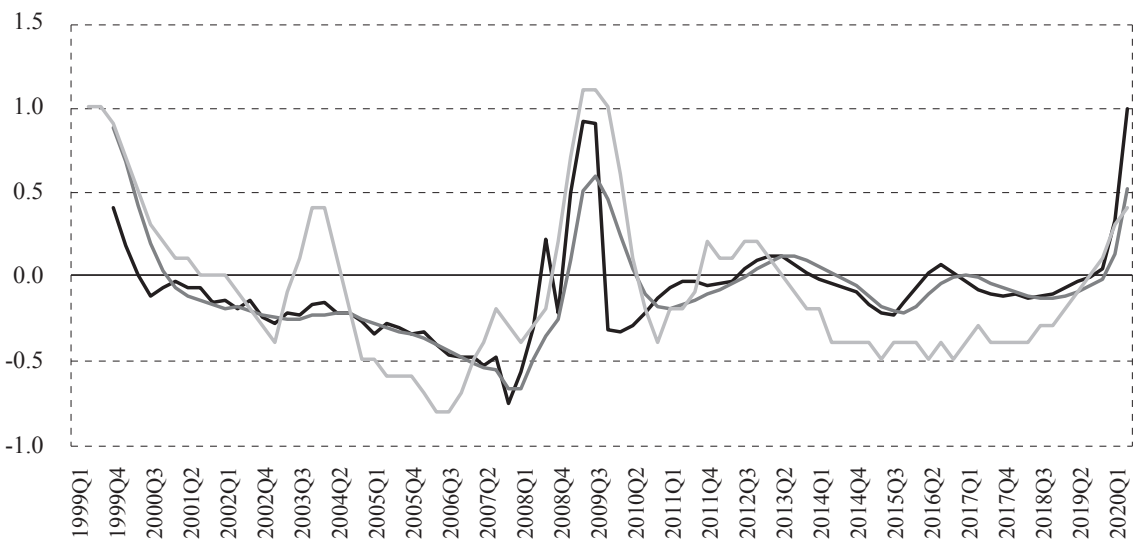

- OLS

OLS noautocorrelation $\mathrm{dU}$

Source: Authors'own calculation based on Labor force survey (LFS) unemployment data by Eurostat (2021). 
Figure A24

Okun's law in Slovenia

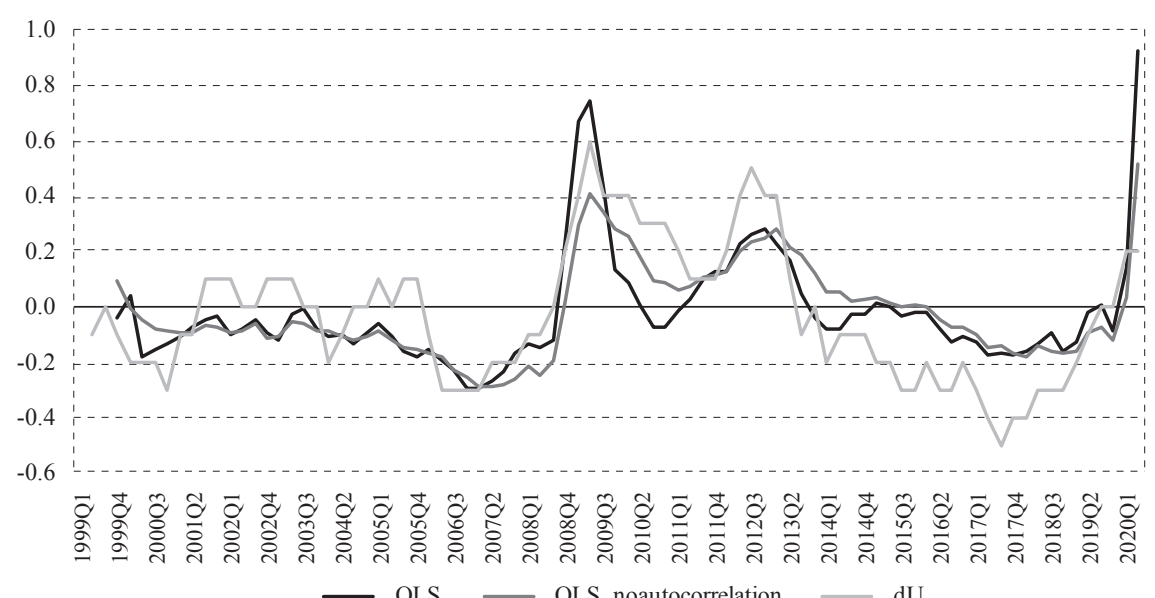

Source: Authors' own calculation based on Labor force survey (LFS) unemployment data by Eurostat (2021).

\section{Figure A25}

Okun's law in Spain

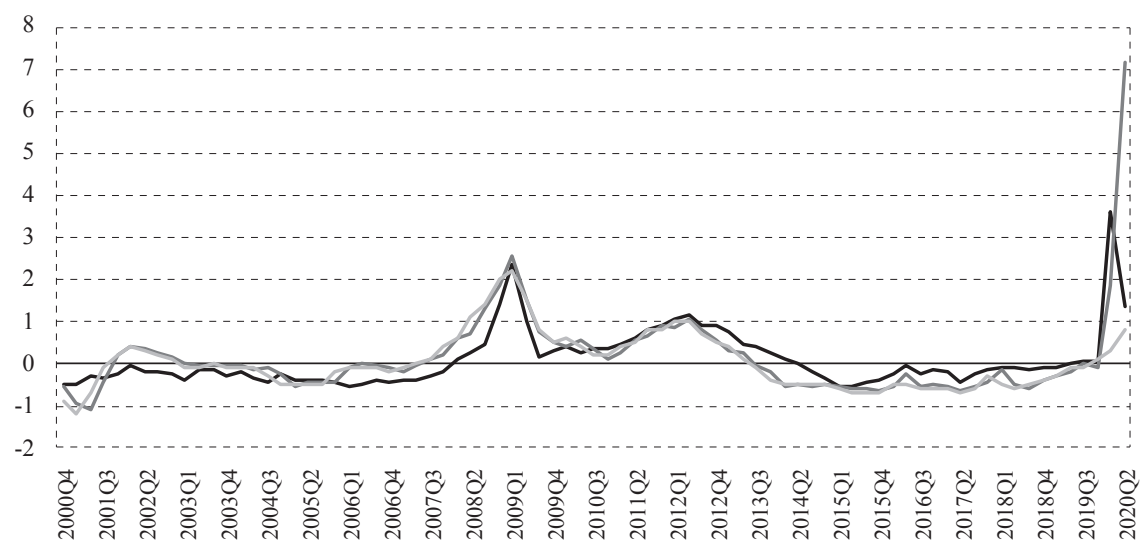

OLS OLS_noautocorrelation dU

Source: Authors' own calculation based on Labor force survey (LFS) unemployment data by Eurostat (2021). 
Okun's law in Sweden

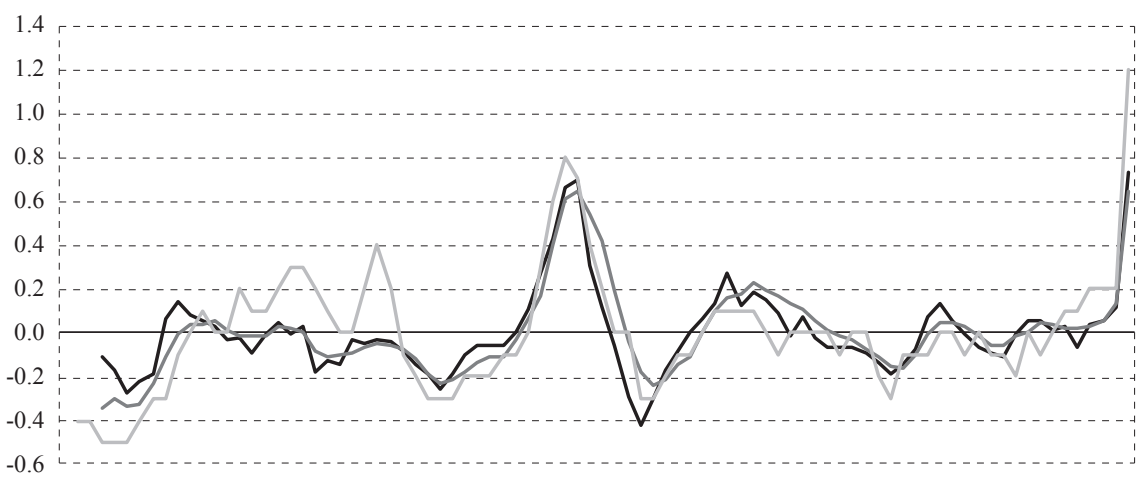

Source: Authors' own calculation based on Labor force survey (LFS) unemployment data by Eurostat (2021). 


\section{TABLE B1}

Description of fiscal measures imposed to fight COVID-19 crisis

\section{Country Fiscal measures (excluding health care system)}

Short-term work arrangement; liquidity support for firms; public loan

Austria guarantees; deferral/reduction of taxes; deferral of social security contributions; government investments to boost the economy

Support for temporary unemployed and self-employed; liquidity

Belgium support; deferral of social security and tax payments; solvency support; support to affected firms/households by subnational governments; a scheme for short-term trade credit insurance

60/40 wage subsidy scheme; support for artists; tourism support; agricultural producers support; tax relief; bonuses to pensions and

Bulgaria minimum pension increase; active labor market policies; increased unemployment benefits; "Keep Me"/ "Employment for you" program; support for workplaces in the hotel and restaurant sector

Deferment of public obligations; deferral of selected parafiscal charges;

Croatia interest-free loans to local governments; subsidization of net minimum; early refund of taxes for individuals; tax obligations of companies reduced/written off; short-time work program

Income support for households; wage subsidy; grants to small

Cyprus businesses and self-employed; support for the tourism sector; tax deferral/reduction; interest subsidy for new business and housing loans; guarantees; supported loans to SMEs

Czechia Wage subsidy; tax deferral/reduction; compensatory bonus for selfemployed persons and small Ltd; public guarantees; grants for tourism

Measures to support workers and businesses affected by the COVID-19

Denmark crisis. Temporary liquidity measures; deferral of tax payments; government guarantees

Cover for wage reduction; business loans to rural companies; guarantees/collateral for bank loans; business loans for liquidity support

Estonia to companies; support to local authorities; investment loans to companies; compensation for direct costs of canceled cultural and sporting events

Lower pension contributions; grants to SMEs and self-employed; expanded parental allowance, social assistance, and unemployment insurance; deferral of tax and pension payments; recapitalization scheme

Finland for state-owned companies; supporting restaurant and catering businesses; guarantees for the Employment Fund, SURE, and the EIB; support to households/businesses; increased public investment; temporary loosening of unemployment insurance benefit eligibility

Public guarantees; liquidity support; deferral of social security and tax payments; accelerated refund of tax credits; support for wages under the short-time work scheme; direct financial support for affected

France microenterprises; deferral of rent and utility payments for affected microenterprises/SMEs; additional investments; nationalizations of companies in difficulty; facilitating granting of exceptional bonuses; extension of unemployment benefits; support for the hardest-hit sectors 
Short-term work subsidy; expanded childcare benefits; easier access to basic income support for the self-employed; grants to small business owners and self-employed persons; interest-free tax deferrals; venture

Germany capital funding for start-ups; temporarily expanded duration of unemployment insurance and parental leave benefits; temporary VAT reduction; grants for hardest-hit SME's; financial support for local governments, credit guarantees for exporters and export-financing banks

Temporary transfers to vulnerable individuals; transfer for employees working in hard-hit firms and for self-employed professionals; extension of unemployment benefits; support for short-term employment,

Greece subsidies to household's loans; liquidity support to hard-hit businesses through loan guarantees, loan and interest payment subsidies, refundable advance payment, rent reductions, and deferred payments of taxes/social security contributions

Employers' social contributions lifted; tax deferral; cancel of tourism development contributions; tax relief for media; subsidizing wages for

Hungary shortened work hours; job creation by supporting investments; support for priority sectors; provision of interest-subsidized and guaranteed credit facilities

Employment wage support scheme: unemployment payment available to those who have lost employment due pandemic; compensation payments to the affected firms; investment in training, education, skills

Ireland development, work placement schemes, recruitment subsidies, job search, and assistance measures; grants for enterprises; waiver of commercial rates; reducing the lending rate for micro and small businesses; support to tourism and culture sector; tax deferral/reduction Measures to preserve jobs and support income of laid-off workers and selfItaly employed; measures to support businesses; tax deferrals; postponement of utility bill payments; measures to support credit supply; state guarantees; measures to support businesses, including grants for SMEs

Loans and guarantees to affected businesses; sectoral support packages;

Latvia use of EU funds to mitigate the impact of the crisis; revenue measures; expenditure measures supporting idle workers and social benefits; investment funds established to support affected large enterprises

Additional funds for support for the self-employed; wage subsidies; co-financing of climate change investment projects; guarantees for agricultural as well as SME loans; increased the borrowing; interest

Lithuania compensation support for SMEs with deferred loans; a new financial instrument for businesses to form portfolios from business loans; cheap loans targeted to hard-hit sectors; launching business support fund; job search allowances; an increase in social benefits; additional funds for the selfemployed and for vocational training; an increase in unemployment benefits

Support individuals unable to work from home; special unemployment benefits; wage subsidies for businesses and self-employed individuals; support for businesses to cover costs of quarantined employees; rent subsidy scheme for SMEs; tax deferral/reduction; in-work benefit and grants Compensation of labor costs for companies; compensation for affected sectors; support for entrepreneurs and self-employed, start-ups and

Netherlands small innovation companies; scaling up of the short-time working scheme; allowances for SMEs to help them finance their fixed costs; deferral of tax; public guarantee schemes 

increased guarantees for enterprises; loans for micro-firms; postponement /cancellation of social insurance contributions; deduction of 2020's losses

Poland for 2021 tax settlement; an allowance for parents of young children related to school closures; solidarity benefit for those who lost job due to crisis; an increase in the unemployment benefit; tourism voucher; interest rate subsidies; support for public investment; liquidity loans and subsidies for micro, small/medium, and large enterprises

Financial support for those temporarily furloughed by their employer; financial incentives to support the progressive reopening and to

Portugal normalize business activity; state-guaranteed credit lines for medium, small and micro enterprises; tax/social security contribution deferrals; financial support for the self-employed; support to the national airline

Covering partially the wages of parents staying home due to school closure;

Romania covering in part the wages of self-employed and workers in danger of being laid off; bonus for corporate income tax payments; deferral of utility payments for SMEs; grants for the businesses; tax deferral/reduction

Wage compensation for affected businesses and self-employed, and

Slovakia subsidies to individuals without income; enhanced unemployment benefits; deferral and waiver of employers' social security contributions; tax deferral; rental subsidies

Tax deferrals; wage subsidies; support to household income; support to

Slovenia corporate liquidity through grants, equity purchase, and government guarantees and credit lines; subsidies for shortened work time; vouchers for tourism

Unemployment benefit for workers temporarily laid off; direct aid for solvency support; tax deferral and reduction; benefit for self-employed workers; assistance programs for vulnerable renters; strengthened unemployment protection; subsidy for vehicle renewal; investment in digitization and innovation in the tourism; benefits for workers who have exhausted unemployment benefits; extension of unemployment Spain benefit to cover workers laid off during the probation period; a temporary monthly allowance for temporary workers; a temporary subsidy for household employees affected by COVID-19; financial assistance to the education system; exemptions of social contributions for impacted companies that maintain employment; deferral of social security debts for companies/self-employed; moratoria of social security contributions for the self-employed and companies in selected industries Liquidity support and guarantees; additional expenditures on wage subsidies for short-term leave, temporary payment of sick leave; loans to SMEs; temporary rent subsidies to vulnerable sectors; temporarily increase of unemployment benefits; expanded active labor market policies; expansion of education, initiatives for green jobs and summer jobs for young people; temporary reduction of employers' social

Sweden security contributions; grants to municipalities and regions; temporary grants to businesses to cover their fixed costs; support to regional public transport, deferral of taxes/social contributions; credit guarantees for Swedish airlines, state credit guarantees for loans to companies; guarantees to the EU for loans to member states, SURE, and to the European Investment Bank for a guarantee fund to support companies 